\title{
Retraining Investment for U.S. Transition from Coal to Solar Photovoltaic Employment
}

\author{
Edward P. Louie ${ }^{1}$ and Joshua M. Pearce ${ }^{2,3 *}$
}

1. School of Public Policy, Oregon State University

2. Department of Materials Science \& Engineering, Michigan Technological University

3. Department of Electrical \& Computer Engineering, Michigan Technological University

* Contact author:

Michigan Technological University

601 M\&M Building

1400 Townsend Drive

Houghton, MI 49931-1295

906-487-1466

pearce@mtu.edu

\begin{abstract}
Although coal remains the largest source of electricity in the U.S., a combination of factors is driving a decrease in profitability and employment in the coal-sector. Meanwhile, the solar photovoltaic (PV) industry is growing rapidly in the U.S. and generating many jobs that represent employment opportunities for laid off coal workers. In order to determine the viability of a smooth transition from coal to PV-related employment, this paper provides an analysis of the cost to retrain current coal workers for solar photovoltaic industry employment in the U.S. The current coal industry positions are determined, the skill set evaluated and the salaries tabulated. For each type of coal position, the closest equivalent PV position is determined and then the re-training time and investment are quantified. These values are applied on a state-by-state basis for coal producing states employing the bulk of coal workers as a function of time using a reverse seniority retirement program for the current American fleet of coal-powered plants. The results show that a relatively minor investment in retraining would allow the vast majority of coal workers to switch to PV-related positions even in the event of the elimination of the coal industry.
\end{abstract}

Keywords: employment; energy industry; solar photovoltaic; coal; jobs; green jobs

\section{Introduction}

Coal remains the largest source of electricity in the U.S. accounting for 39\% of the electricity mix (U.S. EIA, 2014a). In addition, coal power and coal mining are tightly linked, with $93 \%$ of coal consumed used for electricity generation (U.S. EIA, 2014a). Despite the decline in coal jobs due to technological advancements, coal still provides many jobs with the U.S. Energy Information Administration (EIA) and the U.S. Bureau of Labor Statistics (BLS) finding 89,838 and 78,970 employees in coal mining in 2012 and 2013, respectively (U.S. EIA, 2013a; BLS, 2013). While there are no official published numbers on the employees working in coal power plants, studies found that coal-fired power plants employ around 0.18 people in operations and maintenance on a permanent basis per MW (Beamon \& Leckey, 1999; Singh \& Fehrs, 2001). Given there is 336,341 MW of coal generator capacity in the U.S. (U.S. EIA, 2013b), the number of people employed by coal-fired power plants is therefore around 60,541. Thus, coal mining and coal-fired power plants currently employ 
approximately 150,000 people in the U.S., although this is declining.

A combination of factors have and will continue to result in a decline in coal usage and production and the concomitant coal-related employment, which include: 1) price pressure from natural gas (U.S. EIA, 2014b) and renewable energy technologies such as wind (Wiser and Bolinger, 2013) and solar photovoltaic (PV) technology (Branker et al., 2011), 2) increasingly stringent environmental regulations such as the Mercury and Air Toxic Standards (MATS) (U.S. EIA, 2014b), Cross-State Air Pollution Rule (CSAPR) (U.S. EIA, 2014a; EPA, 2014) and the Clean Power Plan Proposed Rule (U.S. EIA, 2014a; Federal Register, 2014), 3) aging coal-fired power plants (U.S. EIA, 2013c; Mufson, 2014), 4) slow growth in electricity demand (U.S. EIA, 2014a), 5) rising mine-mouth prices due to decreasing productivity (U.S. EIA, 2014b), and 6) poor public perception of the coal industry (Jacobe, 2013). Finally, and perhaps most importantly, there is a growing threat of liability due to inherent greenhouse gas emissions that come from coal combustion (Allen, 2003; Allen \& Lord, 2004; Kunreuther \& Michel-Kerjan, 2007; Stott et al., 2013). The potential liability is so large, this alone could threaten the existence of the coal industry in the U.S. as a whole (Heidari and Pearce, 2016).

These factors all contribute to a decline in profitability for continuing to operate coal-fired power plants in both the near and long term. This reduced profitably is driving a decline in coal plants in the U.S. For example, between 2010 and 2012, 14 GW of coal-fired capacity was retired and the EIA's 2014 Annual Energy Outlook projects that a total of $60 \mathrm{GW}$ will be retired by 2020 (U.S. EIA, 2014c). The coal mining industry has been weathering the decline in domestic demand by increasing export (with China and India being the primary importers). This method has been bottlenecked by the lack of export terminals resulting in a push to construct rail lines and export terminals on the coast of the Pacific Northwest. However, these plans have met resistance from the public, Native American tribes, environmental organizations, and now they are also threatened by falling coal prices in Asia and anti-pollution efforts in China (Davis, 2013; Roberts, 2013; Lynch, 2014). In short, the future of the U.S. domestic coal industry is not bright. Both from an economic and an environmental viewpoint, a reverse seniority phase-out model is recommended for coal-fired power plant retirement where the oldest plants (and often the least efficient and most polluting) are retired first.

There is a concern in the public and in particular in regions heavily dependent on coal employment that policy should be developed to ensure a smooth transition to other employment for coal workers whose jobs will be eliminated. The decline in employment in the coal industry is not a new problem and thus the industry has not been attracting many young workers. This is somewhat fortunate, as now the average age of the coal-fired power plants workforce is 48 years, the reduction in number of coal-fired power plants is timely with personnel approaching retirement age (Krishnan \& Associates, 2007). In the short term, the remaining workforce can then be shifted to younger generating units minimizing the retraining and layoffs needed for coal power plant workers. This would incur moving and relocation costs for workers. However, in the medium and long term the eventual phaseout of coal-fired power plants means there will be a need to find employment for coal workers outside of the coal industry (Elliot, 2015). Fortunately, there is one energy industry sector growing at an incredible rate - solar photovoltaic technology that converts sunlight directly into electricity. As solar can be implemented everywhere in the U.S. the need for relocation would be minimized. PV technology has both the scalability, high employment potential and long-term environmental impact to provide a sustainable source of electricity to meet humanity's present and future needs (Pearce, 2002). Since the rapid decrease in the costs of solar PV (Branker et al., 2011) deployment is rising rapidly and generating a large number of jobs (Gordon, et al., 2007; Wei et al., 2010). The U.S. solar industry already employs 209,000 and is creating jobs 12 times higher than employment growth in the overall economy (Solar Foundation, 2016). In addition, solar employment is projected to grow to over 239,000 
jobs in 2016 (Solar Foundation, 2016). The BLS’s more conservative projection for solar photovoltaic installers forecast employment to grow by 24\% from 2012 to 2022 which is still much faster growth than the projected occupational average of 11 percent (BLS, 2014). It thus appears possible for the growth of solar PV-related employment to absorb the layoffs in the coal industry in the next 15 years. It should be pointed out that the solar PV was chosen over the other top renewable energy technologies for the following reasons: wind energy has already expanded to a large fraction of its potential in the U.S. and it is geographically limited (De Vries, et al., 2007), hydro electricity has also been largely developed in the U.S. and further hydro-development continues to be restricted by extensive and complex regulatory procedures, and environmental opposition (Bartle, 2002) and biomass on the large scale needed to replace coal would compete with food production further expanding world hunger and any bioenergy related crops would be cultivated by existing agricultural workers thus restricting the influx of coal workers (Azar et al., 2005; Senauer, 2008). PV is the only technology growing rapidly enough in the U.S. with appropriate employment modalities to absorb the potential coal employment declines.

In order to determine the viability of smooth transition from coal to PV-related employment, this paper provides an analysis of the cost to retrain current coal workers for solar photovoltaic industry employment in the U.S. The current coal industry positions are determined, the skill set evaluated and the salaries tabulated. For each type of coal position, the closest equivalent PV position will be determined and then the re-training time and investment will be quantified. These values will then be applied on a state-by-state basis for coal producing states employing the bulk of coal workers as a function of time using a reverse seniority retirement program for the current American fleet of coalpowered plants. The results will be discussed and policies outlined to provide a smooth transition from coal to solar energy employment in the U.S.

\section{Methods}

The BLS releases an annual national industry specific occupational employment and wage estimates every year (BLS, 2014). This estimate provides a detailed view of the current coal industry positions and information on the skills, education, and salaries of each position. The U.S. Department of Energy's SunShot Initiative (U.S. DOE, 2014) has assembled a solar career map which details jobs across the PV industry, the education, training, and skill requirements of each position, as well as possible pathways to advancement in the PV industry. This information was used to assign an equivalent PV position for each coal position, by matching existing skills, salary and educational attainment (e.g. an engineer in the coal industry matched with an engineering position in the PV industry and an office administrative position in the coal industry would be assigned a similar job in marketing, sales, and permitting in the PV industry). The amount of training needed to equip each coal worker for success in the closest matching PV job was determined based on the educational requirements detailed by the career map versus preexisting skills and knowledge. The time and cost of the required training was determined from trade schools, community colleges, license and certification requirements, and universities as detailed in the sources in the results.

The investment necessary to retrain coal workers for the PV industry is quantified for two scenarios. In the best case scenario (least expensive to retrain) all employees who work non-coal specific positions such as secretary and electrician are able to find a job outside of the PV industry, thus only those working coal specific positions such as roof bolter needs to be retrained for a position in the PV industry. In the worst case scenario (most expensive to retrain), all employees in coal mining will be absorbed into the PV industry. The number of employees by state working in coal mining (U.S. EIA, 
2013a) is used with the assumption that the occupational mix and wage are the same in coal mines across states, the weighted average cost of retraining was multiplied by the number of coal employees in each state and multiplied by the fraction of the jobs that need retraining based on the scenario, the result is the investment each state would need to make in order to retrain its coal workers for jobs in the PV industry. To determine, the weighted average retraining cost per coal worker $\left(\mathrm{C}_{\mathrm{av}}\right)$ the following terms are defined. First, $E_{c}$ is the total number of coal jobs and can be given by:

$$
\mathrm{E}_{\mathrm{c}}=\mathrm{E}_{\mathrm{r}}+\mathrm{E}_{\mathrm{nr}}
$$

where $E_{r}$ is the total number of employees that need retraining and $E_{n r}$ is the total number of employees that need no additional training. Equation 1 can be applied for all coal workers in any given region of study (e.g. a state). As $E_{n r}$ will have no costs for retraining they will not be considered further. The total number of employees that need retraining can be defined as:

$$
E_{r}=\sum_{i=0}^{n} J_{i}
$$

where $\mathrm{n}$ is all the applicable jobs and $\mathrm{J}_{\mathrm{i}}$ is the number of employee in job $\mathrm{i}$. Thus $\mathrm{E}_{\mathrm{r}}$ sums up all of the employees for each coal job, which needs retraining. The average retraining cost per coal worker, which needs retrained is given by:

$$
C_{a v}=\frac{\sum_{i=0}^{n}\left(C_{r i} \times J_{i}\right)}{E_{r}}
$$

where $n$ is all the applicable jobs, $C_{r i}$ is the retraining cost for job $\mathrm{i}$, and $\mathrm{J}_{\mathrm{i}}$ is the number of employees in job $\mathrm{i}$. Thus, the investment (I) needed to fund the retraining was calculated using Equation 2:

$$
I=E_{c s} \times C_{a v}
$$

where $\mathrm{E}_{\mathrm{cs}}$ is the number of coal workers in a state, $\mathrm{s}$.

These calculations were repeated for workers in coal-fired power plants in the U.S. A best and worst case scenario model was conducted for coal-fired power plant workers with the best case scenario being that the number of workers that needed to be retrained is reduced due to the timelines of plant retirement with staff retirement. The worst case scenario would be that all 60,541 employees of coal-fired power plants would have to be absorbed into the PV industry. The National Industry-Specific Occupational Employment and Wage Estimates data from the BLS on power generation covers all electric power generation, transmission, and distribution (BLS, 2014c). Thus data on occupation and employment specific to coal-fired power plants is not available. To work around this problem, power plant specific jobs were selected from the BLS data. Unlike the coal mining industry, the power plant specific jobs require skills that can be translated to jobs in the PV industry without needing retraining. For these power plant specific jobs, the number employed by specifically coal-fired power plants was calculated by multiplying the BLS value by $39 \%$, the fraction of the electricity mix that is generated from coal. The number employed in coal-fired power plants, but hold a non-power plant specific job was determined by subtracting the total number of employees estimated to be working in coal-fired power plants, 60,541, from those working specialized jobs. All non-power plant specific jobs were assigned Solar PV Installer (residential/small commercial) because this career path can be entered by a wide variety of backgrounds, the training is solar specific, and opens the door to many different avenues for advancements.

The funds for retraining investments by each coal producing state need not to be made immediately rather the decline in coal demand and coal mining is expected to decline as coal-fired power plants reach retirement age. More than half of the coal-fired power in the U.S. comes from 
plants built before 1975 thus, with the average age at which power plants retire being 57 years, half of the power plants will reach retirement age by 2030 (U.S. EIA, 2013c; U.S. EIA, 2014c). This is a conservative estimate since the design life of a coal-fired power plant is 25 years; traditionally power plants undergo refurbishment to extend the life to 40 to 50 years (IEA, 2005). Using the EIA's data on coal-fired power plants and adding 57 years to their initial year of operation yields the expected retirement year for coal-power plants (U.S. EIA, 2013c).

The reduction in coal demand, $\mathrm{R}_{\mathrm{CD}}$, from coal-fired power plant retirement is calculated as follows:

$$
R_{C D}=P_{i} \times\left(\frac{0.637 \times 8760 \mathrm{hrs}}{\text { year }}\right) \times\left(\frac{0.54 \text { short tons of coal }}{M W h}\right)
$$

where $\mathrm{P}_{\mathrm{i}}$ is the power measured in MW of coal power plants projected to retire in year i (EIA, 2013c) 0.637 is the capacity factor of a typical coal power plant, they do not run $100 \%$ of the 8760 hours in the year as the plants are shut down for maintenance periodically (EIA, 2014d) and 0.54 is the number of short tons of coal needed for an average coal power plant to produce a MWh (U.S. EIA, 2014f)

The reduction in the number of employees (layoffs) in coal mining, L, industry due to the reduced demand for coal was calculated as follows:

$L=R_{C D} \times p_{C M} \times\left(\frac{\text { Employee }}{2980 h r}\right)$

Where $\mathrm{R}_{\mathrm{CD}}$ is the number of short tons of coal no longer demanded as calculated by equation 5 . All coal mining employees were assumed to be full time employees working $2980 \mathrm{hrs} / \mathrm{yr}$. The productivity of coal mining (man hours per short ton), рсм, was averaged using a weighted average to take into account that underground mining in the eastern part of the U.S. uses more man hours to produce a short ton of coal than surface mining in the west, however, the surface mines out west produce more coal. The weighted average was calculated as follows:

$$
\text { Prod per Employee Hr in State } i \text { Weight }
$$

$p_{C M}=\sum_{j=1}^{j=n}[\overbrace{\left(\frac{C_{j}}{N_{j}}\right)\left(\frac{\text { Employee }}{2080 h r}\right)} \overbrace{\left(\frac{C_{j}}{\sum_{j=1}^{j=n} C_{i}}\right)}]$

Where $C_{j}$ is the coal production in short tons in a State (U.S. EIA, 2013a, Table 1) and $\mathrm{N}_{\mathrm{j}}$ is the number of coal mining employees in State I (U.S. EIA, 2013a, Table 21).

Thus, multiplying the reduction in the number of employees (layoffs) in coal mining industry (equation 6) by the average cost of retraining a laid off employee in the coal industry (equation 3 above) results in the total cost of retraining workers in the coal mining industry for the PV industry for year $\mathrm{i}, \mathrm{C}_{\mathrm{Ti}}$. $C_{T i}=L \times C_{a v}$

\section{Results}

The assembly of jobs across the PV industry and its education, training, and salary has been summarized into Appendix 1 (US DOE, 2014). As can be seen from Appendix 1 there is a wide variety of employment opportunities in the PV industry. These jobs also entail a large variety of skills and training (education). It is also clear from Appendix 1 that the solar PV industry annual pay is attractive at all levels of education, with even the lowest skilled jobs paying a living wage.

Using the job details and educational requirements of each PV job from Appendix 1, a generic 
time and cost to train the typical coal industry positions assigned for success in each PV industry position was assembled as shown in Appendix 2. As can be seen in Appendix 2 high and low cost estimates were made for each training requirement, whenever possible using training available in coal states. Adjustments were occasionally made when assigning retraining costs from Appendix 2 to each coal job in Appendix 3 to take into account the preexisting level of education and training required by each coal industry position. A structural engineer in the coal industry, for example, would not need further training to work as a structural engineer in the PV industry. As can be seen in Appendix 2, the cost of retraining ranged from a few thousands to over a hundred thousand dollars. Thus, the cost of retraining are not trivial for some of the individual coal employees and could be financially burdensome for an individual to pursue themselves. Additionally, as can be seen in Appendix 2, the time necessary for retraining ranges from several months up to 9 years and this assumes one is dedicated to such training. It is clear that transition from work in the coal industry to the PV industry would be much more seamless if coal workers begin retraining years before the need to switch careers because of layoffs.

The BLS survey of the coal mining industry revealed that only $30-35 \%$ of the coal mining job positions are industry specific. Appendix 3, which shows the employment transition between coal mining and PV employment, is sorted such that the jobs identified as needing retraining in even the best case scenario appear first and are identified with a Y in the Training column. Thus, in the best case scenario (lowest cost), only 35\% of the coal mine employees will need to be retrained. It is also clear from Appendix 3, that many jobs in the coal industry that have low educational requirements pay relatively well for unskilled (or low-skilled) work. Thus, many of the coal-specific employees will need to go back to school for additional education in order to qualify for jobs with equivalent salaries in the PV industry.

Three titles in the DOE's PV jobs list (Appendix 1) were not assigned to any positions in the BLS list of jobs (Appendix 3), these included building inspector, lawyer, and electrical inspector with solar expertise. These positions are excluded because the BLS's survey of coal mining jobs did not find a building inspector, lawyer, or an electrical inspector employed by the coal mining industry. This is not to say none exist. As a result, Appendix 2 still details the additional training a building inspector, lawyer, and electrical inspector would need in order to become one with solar expertise also.

Additionally, the material scientist job in the PV industry was also not assigned to any employees in the coal industry due to a lack of qualified personnel.

For coal-fired power plants, $43 \%$ (or 26,060 of 60,541 jobs) are power plant specific with skills which allow them to transition to the PV industry without needing further training, as shown in Appendix 4. Under the worst case scenario, the 34,481 non-power plant specific jobs that remain will require retraining to be residential/small commercial solar PV installers that will cost $\$ 4,295$ per person (Appendix 2) resulting in a total retraining cost of about $\$ 148$ million. It is assumed this cost would be shared by all states, and this cost was not factored into Table 1 or Figure 1 as power generated from coal-fired power plants (coal producing states also possess about 2/3 of the coal-fired power plant generating capacity in the U.S.) are not limited to just coal producing states.

Applying Equation 3, the low and high range of the retraining cost was calculated to be \$5,756 and \$20,660 under the best case scenario and \$6,009 and \$20,863 under the worst case scenario. Using Equation 8 and the EIA's state-level coal mining employment data it was found that the cost to retrain ranged from $\$ 181$ to $\$ 649$ million under the best case scenario and \$539 million to \$1.872 billion for the entire U.S. as shown in the Table. Of all the coal producing states West Virginia will need to invest the most (\$475 million) in retraining as it has the most coal miners. 
Preprint to be published: Edward P. Louie and Joshua M. Pearce. Retraining Investment for U.S. Transition from Coal to Solar Photovoltaic Employment. Energy Economics. (2016). doi:10.1016/j.eneco.2016.05.016

Table 1. Retaining Investments Required for Transition to Solar Economy in Coal Producing States

\begin{tabular}{|c|c|c|c|c|c|c|c|}
\hline \multirow{2}{*}{$\begin{array}{c}\text { Coal- } \\
\text { Producing } \\
\text { State }\end{array}$} & \multicolumn{3}{|c|}{$\begin{array}{l}2012 \text { Average Number of Employees } \\
\text { by State \& Mine Type }\end{array}$} & \multicolumn{2}{|c|}{ Best Case Scenario } & \multicolumn{2}{|c|}{ Worst Case Scenario } \\
\hline & Underground & Surface & Total & Low & High & Low & High \\
\hline Alabama & 3,190 & 1,851 & 5,041 & $\$ 10,155,599$ & $\$ 36,451,471$ & $\$ 30,291,369$ & $\$ 105,171,290$ \\
\hline Alaska & - & 143 & 143 & $\$ 288,088$ & $\$ 1,034,033$ & $\$ 859,287$ & $\$ 2,983,435$ \\
\hline Arizona & - & 432 & 432 & $\$ 870,307$ & $\$ 3,123,792$ & $\$ 2,595,888$ & $\$ 9,012,894$ \\
\hline Arkansas & 70 & 3 & 73 & $\$ 147,066$ & $\$ 527,863$ & $\$ 438,657$ & $\$ 1,523,012$ \\
\hline Colorado & 2,032 & 473 & 2,505 & $\$ 5,046,573$ & $\$ 18,113,655$ & $\$ 15,052,545$ & $\$ 52,262,266$ \\
\hline Illinois & 3,938 & 574 & 4,512 & $\$ 9,089,875$ & $\$ 32,626,272$ & $\$ 27,112,608$ & $\$ 94,134,668$ \\
\hline Indiana & 2,054 & 1,881 & 3,935 & $\$ 7,927,451$ & $\$ 28,453,985$ & $\$ 23,645,415$ & $\$ 82,096,613$ \\
\hline Kansas & - & 6 & 6 & $\$ 12,088$ & $\$ 43,386$ & $\$ 36,054$ & $\$ 125,179$ \\
\hline Kentucky & 11,181 & 5,170 & 16,351 & $\$ 32,940,725$ & $\$ 118,234,081$ & $\$ 98,253,159$ & $\$ 341,133,856$ \\
\hline Louisiana & - & 270 & 270 & $\$ 543,942$ & $\$ 1,952,370$ & $\$ 1,622,430$ & $\$ 5,633,059$ \\
\hline Maryland & 213 & 263 & 476 & $\$ 958,950$ & $\$ 3,441,956$ & $\$ 2,860,284$ & $\$ 9,930,874$ \\
\hline Mississippi & - & 211 & 211 & $\$ 425,081$ & $\$ 1,525,741$ & $\$ 1,267,899$ & $\$ 4,402,131$ \\
\hline Missouri & - & 32 & 32 & $\$ 64,467$ & $\$ 231,392$ & $\$ 192,288$ & $\$ 667,622$ \\
\hline Montana & 320 & 913 & 1,233 & $\$ 2,484,002$ & $\$ 8,915,823$ & $\$ 7,409,097$ & $\$ 25,724,301$ \\
\hline New Mexico & 435 & 856 & 1,291 & $\$ 2,600,849$ & $\$ 9,335,221$ & $\$ 7,757,619$ & $\$ 26,934,365$ \\
\hline $\begin{array}{l}\text { North } \\
\text { Dakota }\end{array}$ & - & 1,228 & 1,228 & $\$ 2,473,929$ & $\$ 8,879,668$ & $\$ 7,379,052$ & $\$ 25,619,985$ \\
\hline Ohio & 1,969 & 1,222 & 3,191 & $\$ 6,428,589$ & $\$ 23,074,121$ & $\$ 19,174,719$ & $\$ 66,574,407$ \\
\hline Oklahoma & 55 & 144 & 199 & $\$ 400,905$ & $\$ 1,438,969$ & $\$ 1,195,791$ & $\$ 4,151,773$ \\
\hline Pennsylvania & 6,120 & 2,807 & 8,927 & $\$ 17,984,334$ & $\$ 64,551,137$ & $\$ 53,642,343$ & $\$ 186,245,608$ \\
\hline Tennessee & 175 & 188 & 363 & $\$ 731,300$ & $\$ 2,624,853$ & $\$ 2,181,267$ & $\$ 7,573,334$ \\
\hline Texas & & 2,918 & 2,918 & $\$ 5,878,603$ & $\$ 21,100,058$ & $\$ 17,534,262$ & $\$ 60,878,759$ \\
\hline Utah & 1,576 & 35 & 1,611 & $\$ 3,245,521$ & $\$ 11,649,141$ & $\$ 9,680,499$ & $\$ 33,610,583$ \\
\hline Virginia & 3,763 & 1,235 & 4,998 & $\$ 10,068,971$ & $\$ 36,140,538$ & $\$ 30,032,982$ & $\$ 104,274,174$ \\
\hline $\begin{array}{l}\text { West } \\
\text { Virginia }\end{array}$ & 17,085 & 5,701 & 22,786 & $\$ 45,904,676$ & $\$ 164,765,566$ & $\$ 136,921,074$ & $\$ 475,388,419$ \\
\hline Wyoming & 250 & 6,754 & 7,004 & $\$ 14,110,258$ & $\$ 50,645,924$ & $\$ 42,087,036$ & $\$ 146,125,713$ \\
\hline Total & 54,426 & 35,310 & 89,736 & $\$ 180,782,146$ & $\$ 648,881,016$ & $\$ 539,223,624$ & $\$ 1,872,178,320$ \\
\hline
\end{tabular}

Coal producing States should invest in funding the cost of retraining ideally years before the retirement of power plants so workers can go directly from one job to the next with no delay, but if the investments are made in parallel with the retirement of coal-fired power plants then the year at which funds need to be available is shown in Figure 1. As shown in Figure 1, most of the retraining investments will have to be made between now and 2040, if the age of coal plant retirement plan is used. It should be noted here that this is an optimistic approximation for coal industry longevity and assumes none of the coal-related externalities are incorporated into the market. While the shape of the 
curves in Figure 1 is a good estimate, resolution was lost due to the averaging of coal production (short tons) per employee-hr, thus for actual dollar amounts the values in Table 1 are more representative and should be used for policy formation.

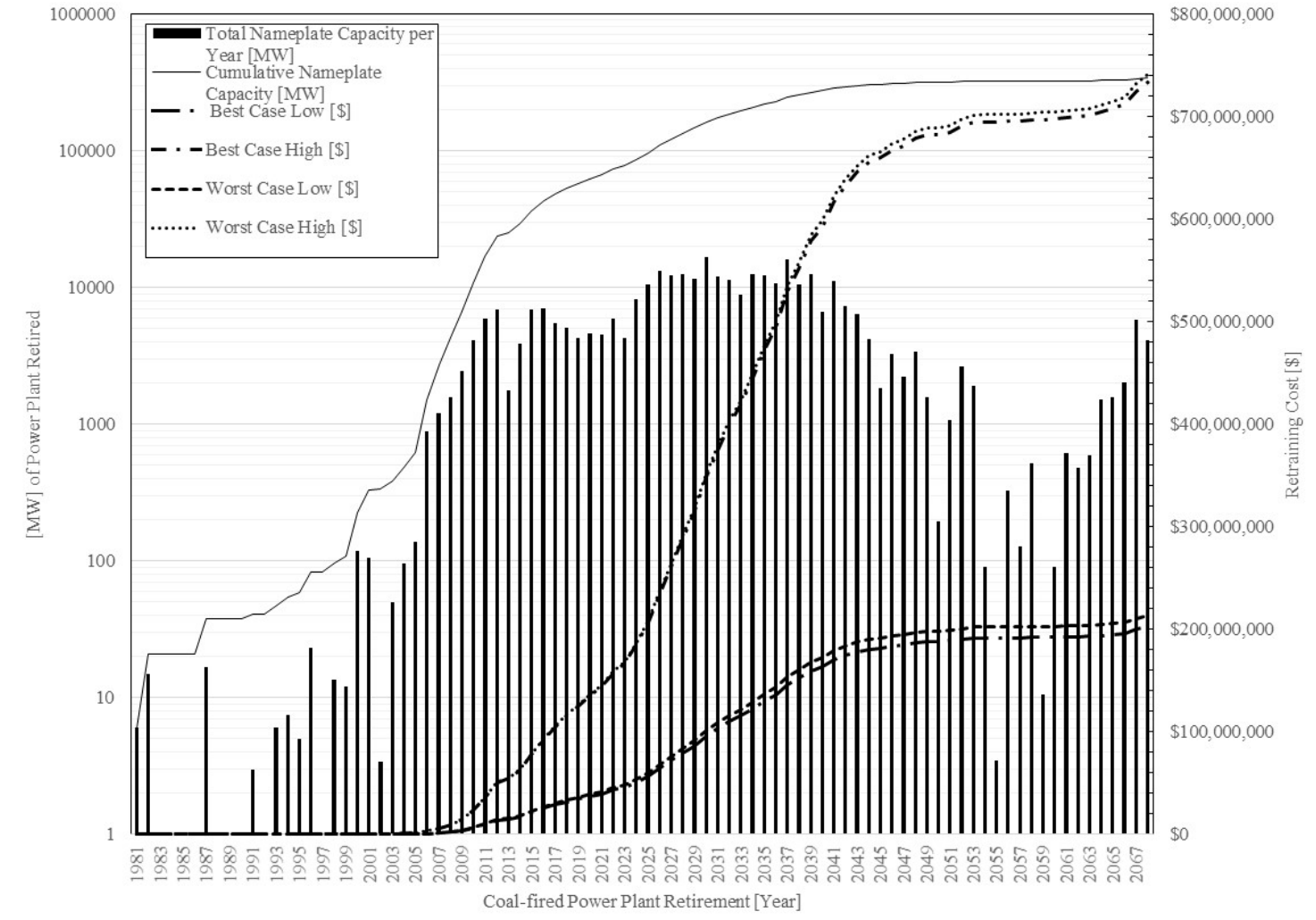

Figure 1. MW of power plants retired and retraining costs, and coal-fired power plants retirements per year.

\section{Discussion}

As can be seen in Table 1 for the low best case scenario, if it is assumed that only coal-specific jobs require retraining only $\$ 180$ million is needed in the event of the complete elimination of the coal industry. In the worst case high estimate this retraining cost is expanded by a factor of ten. To cover these costs four policy scenarios are considered and their impacts discussed: i) employees pay for their own retraining, ii) the coal industry pays for their employee retraining, iii) programs are established in individual states to provide this training, and iv) the U.S. federal government funds the coal to solar transition.

\subsection{Coal Employees Self-fund Retraining}

In this status-quo scenario coal employees must shoulder the entire burden of retaining themselves when their employer closes the mine or power plant and no policy intervention is necessary. As stated above many coal employees are old and will simply retire early with less retirement income as the prospect of going to school for several years to match their current income so near retirement will not be appealing. Young unskilled coal workers with jobs specific to the coal industry will be the most severely financially penalized by this scenario. For example, even in their best case scenario, mine shuttle car operators would lose nearly half of their income even after being unemployed for 3 months to train as mechanical assemblers. Coal workers that prepare for the loss of their coal jobs by, 
for example, training in the evenings, use vacation time and the weekends will be in a much better position than their colleagues that wait to retrain until after becoming unemployed. As some of the costs of retraining can be substantial for individuals, considering their future employment and investing in retaining for green jobs in the solar industry while they still have an income is important. It should be noted that the transition from coal to PV jobs would not be occurring in a vacuum and it is likely that the coal workers will have competition for increasingly prized 'green jobs' (Greenhouse, 2008; Engel \& Kammen, 2009; Wei et al. 2010; Bowen, 2012; Lehr et al., 2012; Yi, 2013).

This scenario has the advantage that it will not cost the coal industry, state and federal government anything, but has the disadvantage (from a coal employer perspective) that attracting young coal workers (e.g. generation Z) will be even more difficult than it is already. Generation $\mathrm{Z}$ are loosely defined as those born after 1995 and who are now 18 and under. Generation Z represents the future of the energy industry, who are currently making the decision on the type of training for their future careers. A recent marketing study found a distinct break in the attitudes of the more materialistic and narcissistic Generation Y, with $60 \%$ of Gen Zers wanting jobs that had a social impact, about double those of Generation Y (Sparks and Honey, 2014). As the coal industry is already suffering public perception challenges (e.g. a 2008 MIT Energy Survey found substantial majorities of Americans oppose the location of coal power plants in their area (Ansolabehere \& Konisky, 2009)), the coal industry already suffers from a reduced pool of potential workers and thus lower quality potential employees from which to hire. As this trend continues in the future, inferior workers would be expected to further depress productivity thereby hastening mine and plant closings because they would no longer be economically competitive.

\subsection{Policies Promoting Coal Industry Paying for Employee Retraining}

In the second scenario, the coal industry is either mandated to pay for their employee retraining or chooses to do so on their own. In this scenario the coal industry would be financially burdened to set aside a fraction of their income over a number of years to ensure that all of their employees could find employment when the mine or power plant closed. The industry could either arrange for this financial burden to be shared as a whole through an insurance-like program or each individual company could be responsible for retraining their own employees. There is some precedence for such a program in the industry. For example, the Surface Mining Control and Reclamation Act of 1977, mandates that active mining operations pay fees into the Abandoned Mine Reclamation Fund that are then used to finance reclamation of abandoned mine lands (US. DOI OSMRE, 2014). Financing a "Coal Employee Retraining Fund" could operate in much the same way.

Although the overall training costs are substantial as seen in Figure 1 and Table 1, these burdens need to be put into perspective. According to the National Mining Association, coal mining activity generated \$37.4 billion in direct GDP in the U.S. 2011 (2013). Thus, even in the high estimate worst case scenario where all coal-workers need to be retrained specifically for the solar industry using the most expensive training available the $\$ 1.8$ billion total retraining investment is only $5 \%$ of coal mining's economic impact for a single year. Summarizing many studies that investigated coal industry subsidies Badcock and Lenzen (2010) found coal-fired power has benefited from over \$38 billion in U.S. financial subsidies between 1994 and 2008. Again, this puts the training requirement in context as the coal industry would need to invest what amounts to less than $5 \%$ of what it has received in government aid over that period.

Although the political viability of such mandates occurring at either the State and/or Federal levels are outside the scope of this paper, governments may consider such mandates on the coal industry either as a way to maintain employment without spending taxpayer money or as a way to 
recoup subsidies of environmental externalities. Similar to what has been found with financial subsidies, the absolute external costs of coal-fired power are much larger than those of competing electricity-generation technologies (Koplow \& Dernbach, 2001; Badcock \& Lenzen, 2010). There are several externalities associated with coal including reduction in life expectancy, increased hospital admissions, degradation and soiling of buildings, reduction in crop yields, ecosystem loss and degradation, and global warming, which makes up $80 \%$ by an estimate of the controversial costs of future climate change (European Commission, 1995;1999). The externalities associated with the coal industry completely dwarf and training costs. For example, the Koplow and Dernbach (2001) analysis found annual externalities of around $\$ 420$ billion for the U.S. alone. A more recent comprehensive review of the externalities associated with the coal industry (Epstein, et al., 2011) finds that the best estimate for the total economically quantifiable costs, based on a conservative weighting, amount to some $\$ 345.3$ billion, adding close to $17.8 \$ / \mathrm{kWh}$ of electricity generated from coal. The Epstein et al. (2011) low estimate is $\$ 175$ billion, or over $9 \$ / \mathrm{kWh}$, which is nearly at the current U.S. electrical retail cost. The study points out that the true monetizable costs of coal-fired electricity could be as much as the upper bounds of $\$ 523.3$ billion, adding close to $26.89 \$ / \mathrm{kWh}$, which is more expensive than any residential electric rate in the nation. As these quantifiable externalities are borne by the general public, the relatively modest investment to retrain all of the coal industry's employees for positions in the PV industry may in the future become politically feasible.

However, no legal mandate may be necessary for the coal industry to provide funding for the retraining of their workers. First, it should be pointed out that the coal industry is not a monolithic entity. Coal companies are competing against one another for market share and profit. As pointed out in Section 4.1 the pool of high-quality coal employees is already artificially small because of the poor public perception and the increasing public awareness of the cost of coal-related externalities. Public perception of the coal industry acting in good faith towards their workers can be extremely important as employment is the remaining primary benefit of the industry. Thus, it may not be a wise strategy to garner additional public support to have large executive compensation while thousands of low-skilled coal employee positions are being terminated. For example, using SEC filings Forbes reports that Brett Harvey, the CEO of Consol Energy was compensated over \$15.5 million (Forbes, 2012), which would be more than enough to retrain all of Consol's coal employees for jobs in the PV industry. Thus, to improve public support a coal company could voluntarily slightly decrease CEO salaries to ensure their entire workforce had a socio-economically stable future. This would work best if the CEO himself made the gesture. For example, Mr. Harvey could join the club of "Dollar-a-year men”, which historically were business and government executives who helped the U.S. government mobilize and manage American industry during periods of war, especially World War I and II. More recently, many very successful executives who take a one-dollar salary also choose not to take any other forms of compensation. In addition to Harvey, the CEOs of other companies like Peabody Energy Corporation, Alliance Resource Partners, Arch Coal, Inc. and Cloud Peak Energy receive substantial compensation packages and may want to take advantage of the good will generated by such a gesture. While the companies are in business, providing the retraining of the workers could not only help partially protect coal entities from unfavorable legislation by increasing good will, but it could also directly help their competitiveness by improving company morale and enlarging the possible pool of employees to hire. This would improve the quality of potential employees and improve productivity and thus profits. There is some evidence that companies are willing to make these types of investments in other industries. Cappelli (2004) found that employers were willing to retrain workers who are at risk of layoff for new jobs was associated with preserving the social capital among current employees. Thus, employers who make greater use of work systems that rely on social capital are more likely to retrain 
their workers (Cappelli, 2004). The degree of social capital necessary in the coal industry is uncertain, however, such employee-friendly policies would be expected to lift morale within the company and ensure higher productivity until the end. The policy implementation could use means such as: scholarships, education vouchers and grants for employees to universities, colleges, community colleges, and PV certification programs outlined in Appendix 2.

\subsection{Individual States Policies to Provide “Coal to Solar” Transition Programs}

As it is becoming more clear that energy policy needs to be informed by dynamic life cycle carbon emissions (Kenny et al., 2010), and federal governments appear limited in their capacity to enact meaningful policies, many of the world's governments at the State or Provincial and even municipal-level have produced policies intended to reduce coal use and improve the cost-effectiveness of renewable energy to mitigate the risks of climate change (Engel, 2006; Lutsey \& Sperling, 2008; Wheeler, 2008; Rabe, 2009; Branker \& Pearce, 2010; Bierbaum et al., 2013). Considering the far more aggressive and expensive policy changes to enable a transition to renewable energy a policy of funding coal employee retraining to keep these workers relevant in the next twenty years appears possible. The investments necessary for the individual coal-producing States are summarized in Table 1, and are well within any of the State discretionary budgets.

Implementation of a State-level policy for coal worker retraining would benefit similarly to case 1 , where pre-emptive action would cost less in the long term so the state could avoid unemployment benefits for coal workers that could directly transition to PV jobs. Implementation of the retraining could take several forms: i) scholarships, education vouchers and grants for coal employees to State universities, colleges and community colleges, ii) subsidized expansion of solar industry training such as the workshops and classes provided by entities like SEI, iii) State sponsored free courses and certificates for PV positions, and iv) no, low-interest or subsidized loans for education and retraining.

\subsection{U.S. Federal Government Policy to Fund the Coal to Solar Transition}

In this scenario the U.S. federal government funds the coal to solar transition alone. The motive for the Federal government to make such an expenditure is the same as the aggregate of the State benefits outlined in Section 4.3. The costs, however, are also the aggregate and summarized in the bottom row of Table 1. Even if completely subsidized by the federal government these figures (ranging from \$180 million to \$1.87 billion) are trivial compared to the United States government budget of \$3.445 trillion in fiscal year 2013 with 2.775 trillion in receipts (United States Office of Management and Budget, 2014). This expenditure needed to maintain full employment of all present coal workers in the solar industry would be only $0.0052 \%$ and $0.0543 \%$ of the federal budget, respectfully. These values actually represent an over-estimate as the Federal government would have economies of scale to help drive down the cost of retraining. For example, the government could fund the development of open access solar PV industry curricula, which then could be used by community colleges throughout the nation to drive down the cost estimates in Appendix 2. If some (or all) of this curricula could be delivered in an online environment it would allow coal employees to complete the training at night or during the weekends while they maintained their current positions. The Federal Government would also be in a position to negotiate reduced rates for coal-employee cohorts to obtain university degrees from both state and private universities. The implementation of the retraining could follow the same policy mechanisms used by the states individually, however, they would be scalable to the entire 
nation, which would allow the lowest cost retraining option to be utilized.

\section{Limitations and Future Work}

This study had several limitations. First, the selection of closest positions between the coal and solar industry used was open to error and will in many cases be dependent on particular individual's interests along with specific job and training opportunities. This mobility of workers from one industry to another varies widely (Judy \& D'Amico, 1997) although the ability for remote education is enabling more mobility in some sectors (Denkenberger, et al., 2015). As noted earlier there is substantial online training possible in the solar industry. Although individual workers transition may be different than those outlined here, the aggregate values generated, however, are reasonable and adequate for policy making.

In addition, this study assumed that the occupational mix was approximately the same from state to state, however, depending on the type of coal-related work in a given state this could vary and should be quantified in future work. The largest limitation for this study is the assumption that coal fired power plants will only be closed following the retirement strategy based on age shown in Figure 1. This assumption is likely extremely optimistic as the forces driving coal's lack of economic competitiveness are likely to accelerate plant closings beyond simple age. For example, in the last year Patriot Coal Corp., Walter Energy Inc. and Alpha Natural Resources Inc. along with Arch Coal Inc., the second largest coal miner in the U.S., have filed for bankruptcy (Klein and Loh, 2016). In addition, the market cap for publicly trade U.S. coal miners has decreased by more than a factor of ten in the last 5 years (Klein and Loh, 2016). In addition, Forbes has pointed out that the COP21 climate change conference could further weaken coal companies financially (Trefis, 2015) and this could be further exacerbated if they begin to held liable for the costs of climate change (Allen, 2003; Heidari and Pearce, 2016) the entire industry would be shut down in a short time period and Figure 1 would look more like a step function. If this is the case, the full costs of the retraining summarized in Table 1 would need invested on a shorter timeline, however, as shown in Section 4, in all but the first scenario (worker funded) the cost is small compared to the revenue of the funders.

\section{Conclusions}

As the coal industry in the U.S. declines and the PV industry expands, this study quantified the costs of retraining all coal-industry employees for jobs in the solar photovoltaic industry. To cover these costs four policy scenarios are considered and their impacts discussed: i) employees pay for their own retraining, ii) the coal industry pays for their employee retraining, iii) programs are established in individual states to provide this training, and iv) the U.S. federal government funds the coal to solar transition. The benefits and drawbacks of each scenario are outlined. Even if completely subsidized by the federal government these figures (ranging from $\$ 180$ million to $\$ 1.87$ billion) would be only amount to $0.0052 \%$ and $0.0543 \%$ of the U.S. federal budget, respectfully. Coal to PV transition retraining could be implemented as: i) scholarships, education vouchers and grants for coal employees to universities, colleges, community colleges and certification programs, ii) subsidized expansion of solar industry training such as the workshops and on-line classes, iii) government-sponsored free courses and certificates for PV positions, and iv) no, low-interest or subsidized loans for education and retraining.

\section{References}

Allen, M. (2003). Liability for climate change. Nature, 421(6926), 891-892. 
Allen, M. R., \& Lord, R. (2004). The blame game. Nature, 432(7017), 551-552.

Ansolabehere, S., \& Konisky, D. M. (2009). Public attitudes toward construction of new power plants. Public Opinion Quarterly, 73(3), 566-577.

Azar, C., Simpson, R. D., Toman, M. A., \& Ayres, R. U. (2005). Emerging scarcities-bioenergy-food competition in a carbon constrained world. Scarcity and growth revisited: Natural resources and the environment in the new millennium, 98-120.

Badcock, J., \& Lenzen, M. (2010). Subsidies for electricity-generating technologies: A review. Energy Policy, 38(9), 5038-5047.

Bartle, A. (2002). Hydropower potential and development activities. Energy Policy, 30(14), 1231-1239.

Beamon, A. J., \& Leckey, T. J. (1999, September 9). Trends in Power Plant Operating Costs. Issues in Midterm Analysis and Forecasting 1999. Retrieved August 6, 2014, from http://www.eia.gov/oiaf/issues/power_plant.html

Bierbaum, R., Smith, J. B., Lee, A., Blair, M., Carter, L., Chapin III, F. S., Fleming, P., Ruffo, S., Stults, M., McNeeley, S., Wasley, E., \& Verduzco, L. (2013). A comprehensive review of climate adaptation in the United States: more than before, but less than needed. Mitigation and Adaptation Strategies for Global Change, 18(3), 361-406.

Bowen, A. (2012). 'Green'growth,'green'jobs and labor markets. World bank policy research working paper, (5990).

Branker, K., \& Pearce, J. M. (2010). Financial return for government support of large-scale thin-film solar photovoltaic manufacturing in Canada. Energy Policy, 38(8), 4291-4303.

Branker, K., Pathak, M. J. M., \& Pearce, J. M. (2011). A review of solar photovoltaic levelized cost of electricity. Renewable and Sustainable Energy Reviews, 15(9), 4470-4482.

Bureau of Labor Statistics. (2014a). NAICS 212100 - Coal Mining. In May 2013 National IndustrySpecific Occupational Employment and Wage Estimates. Retrieved July 27, 2014 from http://www.bls.gov/oes/current/naics4_212100.htm

Bureau of Labor Statistics. (2014b). Solar Photovoltaic Installers. In Occupational Outlook Handbook. Retrieved August 1, 2014 from http://www.bls.gov/ooh/construction-and-extraction/solarphotovoltaic-installers.htm\#tab-6

Bureau of Labor Statistics. (2014c). NAICS 221100 - Electric Power Generation, Transmission and Distribution. In May 2013 National Industry-Specific Occupational Employment and Wage Estimates. Retrieved August 8, 2014 from http://www.bls.gov/oes/current/naics4_221100.htm

Cappelli, P. (2004). Why Do Employers Retrain At-Risk Workers? The Role of Social Capital. Industrial Relations: A Journal of Economy and Society, 43(2), 421-447.

Davis, R. (2013, December 13). Viability of Oregon, Washington coal export terminals threatened by falling Asian prices. The Oregonian. Retrieved August 4, 2014 from http://blog.oregonlive.com/environment_impact/print.html?entry=/2013/12/viability_of_oregon _washington.html

Denkenberger, D., Way, J., \& Pearce, J. M. (2015). Educational Pathways to Remote Employment in Isolated Communities. Journal of Human Security, 11(1), 34-44.

Elliott, D. (2015). Green Jobs and the Ethics of Energy. In Ethical Engineering for International Development and Environmental Sustainability (pp. 141-164). Springer London.

Engel, K. (2006). State and local climate change initiatives: what is motivating state and local governments to address a global problem and what does this say about federalism and environmental law. Urb. Law., 38, 1015.

European Commission. (1995). ExternE_Externalities of energy, vol. 3 Coal \& Lignite. European Commission, Directorate-General XII, Science, Research and Development, Luxembourg. 
European Commission. (1999). ExternE-Externalities of energy, vols. 1-10. European Commission, Directorate-General XII, Science, Research and Development, Luxembourg.

Engel, D., \& Kammen, D. M. (2009). Green jobs and the clean energy economy. Copenhagen Climate Council.

Epstein, P. R., Buonocore, J. J., Eckerle, K., Hendryx, M., Stout III, B. M., Heinberg, R., Clapp, R.., May, B., R. N.L., Ahern, M.M., Doshi, S.K. \& Glustrom, L. (2011). Full cost accounting for the life cycle of coal. Annals of the New York Academy of Sciences, 1219(1), 73-98.

Federal Register. (2014). Carbon Pollution Emission Guidelines for Existing Stationary Sources: Electric Utility Generating Units A Proposed Rule by the Environmental Protection Agency. Retrieved August 6, 2014 from: https://www.federalregister.gov/articles/2014/06/18/201413726/carbon-pollution-emission-guidelines-for-existing-stationary-sources-electric-utilitygenerating\#h-9

Forbes. (2012). CEO Compensation. \#97 Brett Harvey. Retrieved August 16, 2014 from http://www.forbes.com/lists/2012/12/ceo-compensation-12_J-Brett-Harvey_33BV.html

Gordon, K., Hays, J., Sompolinsky, L., Tan, E., \& Tsou, J. (2007). Community Jobs in The Green Economy. Apollo Alliance: Urban Habitat

Greenhouse, S. (2008, March 26). Millions of jobs of a different collar. New York Times. Retrieved August 16, 2014 from http://www.nytimes.com/2008/03/26/business/businessspecial2/26collar.html?pagewanted=all

Heidari, N. and Pearce, J.M. (2016) A review of greenhouse gas emission liabilities as the value of renewable energy for mitigating lawsuits for climate change related damages. Renewable and Sustainable Energy Reviews, 55, 899-908.

Jacobe, D. (2013). Americans Want More Emphasis on Solar, Wind, Natural Gas Oil, nuclear, and coal are more popular with Republicans and in the South. Gallup. Retrieved August 5, 2014 from http://www.gallup.com/poll/161519/americans-emphasis-solar-wind-natural-gas.aspx

Judy, R. W., \& D'Amico, C. (1997). Workforce 2020: Work and Workers in the 21st Century. Hudson Institute, Indianapolis.

Kenny, R., Law, C., \& Pearce, J. M. (2010). Towards real energy economics: energy policy driven by life-cycle carbon emission. Energy Policy, 38(4), 1969-1978.

Klien, J.X. and Loh, T. The Coal Miner 'On Everybody;s List' as Next Bankruptcy Victim. Bloomberg Business. 1.20.2016. Retrieved March 21, 2016 from:

http://www.bloomberg.com/news/articles/2016-01-21/the-coal-miner-on-everybody-s-list-asnext-bankruptcy-victim

Koplow, D. \& Dernbach. J. (2011). Federal fossil fuel subsidies and greenhouse gas emissions: a case study. Annual Review of Energy and Environment, 21, 361-389

Krishnan, R. \& Associates. (2007). Easing the Exodus: Innovative Personnel Strategies Can Combat The Loss Of Technical Skills. Penn Energy Jobs, 2, 2-7. Retrieved August 5, 2014 from http://www.krishnaninc.com/Tech_Paper_KA_Recruiting_Article.pdf

Kunreuther, H. C., \& Michel-Kerjan, E. O. (2007). Climate change, insurability of large-scale disasters and the emerging liability challenge (No. w12821). National Bureau of Economic Research.

Lehr, U., Lutz, C., \& Edler, D. (2012). Green jobs? Economic impacts of renewable energy in Germany. Energy Policy, 47, 358-364.

Lutsey, N., \& Sperling, D. (2008). America's bottom-up climate change mitigation policy. Energy Policy, 36(2), 673-685.

Lynch, D. J. (2014). China’s Clean-Fuel Focus Tests U.S. Coal-Export Lifeline: Energy. Retrieved August 6, 2014 from http://www.bloomberg.com/news/2014-06-10/china-s-clean-fuel-focus- 
tests-u-s-coal-export-lifeline.html

Mufson, S. (2014). Vintage U.S. coal-fired power plants now an 'aging fleet of clunkers'. The Washington Post. Retrieved August 4, 2014 from http://www.washingtonpost.com/business/economy/a-dilemma-with-aging-coal-plants-retirethem-or-restore-them/2014/06/13/8914780a-f00a-11e3-914c-1fbd0614e2d4_story.html

National Mining Association. (2013). The Economic Contributions of U.S. Mining (2011), September 2013. Retrieved August 18, 2014 from http://www.nma.org/pdf/economic_contributions.pdf

Pearce, J. M. (2002). Photovoltaics — a path to sustainable futures. Futures, 34(7), 663-674.

Rabe, B. G. (2009). Second-generation climate policies in the states: proliferation, diffusion, and regionalization. Changing climates in North American Politics: institutions, policymaking, and multilevel governance. MIT Press, Cambridge, 67-86.

Roberts, D. (2013). Goldman Sachs says coal-export terminals are a bad investment. Grist. Retrieved August 4, 2014 from http://grist.org/climate-energy/goldman-sachs-says-coal-export-terminalsare-a-bad-investment/

Senauer, B. (2008). Food market effects of a global resource shift toward bioenergy. American Journal of Agricultural Economics, 90(5), 1226-1232.

Singh V. \& Fehrs J. (2001). The Work That Goes Into Renewable Energy. Renewable Energy Policy Project, 13. Retrieved August 4, 2014 from http://www.globalurban.org/The_Work_that_Goes_into_Renewable_Energy.pdf

The Solar Foundation. (2016). 2015 National Solar Jobs Census . Retrieved 3.24.2016 from Solar Foundation, 2016 http://www.thesolarfoundation.org/wp-content/uploads/2016/01/2015Census-FactsheetFINAL1-12-16.pdf

Sparks \& Honey Agency. (2014). Meet Generation Z: Forget everything you learned about Millennials. Spark and Honey. Retrieved August 15, 2014 from http://www.slideshare.net/sparksandhoney/generation-z-final-june-17

Stott, P. A., Allen, M., Christidis, N., Dole, R. M., Hoerling, M., Huntingford, C, Pall, P. Perlwitz, J. \& Stone, D. (2013). Attribution of weather and climate-related events. In Climate Science for Serving Society (pp. 307-337). Springer Netherlands.

Trefis, I. (2015) Paris Climate Agreement Spells Trouble For Coal. Forbes Investing. Dec. 17, 2015. Retrieved March 21, 2016 from: http://www.forbes.com/sites/greatspeculations/2015/12/17/paris-climate-agreement-spellstrouble-for-coal/\#10a7dd42ea43

U.S. Department of Energy, Office of Energy Efficiency \& Renewable Energy. (2014). Solar Career Map. Retrieved July 30, 2014 from http://energy.gov/eere/sunshot/solar-career-map

U.S. Department of Interior, Office of Surface Mining Reclamation and Enforcement. (2014). Surface Mining Control and Reclamation Act (SMCRA) 1977. In Laws, Regulations, and Guidance. Retrieved August 5, 2014 from http://www.osmre.gov/LRG.shtm

U.S. Energy Information Administration. (2014a). What is the role of coal in the United States? In Energy In Brief. Retrieved August 6, 2014 from http://www.eia.gov/energy_in_brief/article/role_coal_us.cfm

U.S. Energy Information Administration. (2014b). Market Trends: Coal. In Annual Energy Outlook 2014. Retrieved August 6, 2014 from http://www.eia.gov/forecasts/aeo/MT_coal.cfm 
U.S. Energy Information Administration. (2014c). AEO2014 projects more coal-fired power plant retirements by 2016 than have been scheduled. In Today In Energy. Retrieved August 5, 2014 from http://www.eia.gov/todayinenergy/detail.cfm?id=15031

U.S. Energy Information Administration. (2014d). What is a capacity factor? In Frequently Asked Questions. Retrieved August 7, 2014 from http://www.eia.gov/tools/faqs/faq.cfm?id=187\&t=3

U.S. Energy Information Administration. (2014e). Electric Power Monthly. Table 6.7.A. Capacity Factors for Utility Scale Generators Primarily Using Fossil Fuels, January 2008-May 2014. In Electric Power Monthly. Retrieved August 7, 2014 from http://www.eia.gov/electricity/monthly/epm_table_grapher.cfm?t=epmt_6_07_a

U.S. Energy Information Administration. (2014f). How much coal, natural gas, or petroleum is used to generate a kilowatt hour of electricity? In Frequently Asked Questions. Retrieved August 7, 2014 from http://www.eia.gov/tools/faqs/faq.cfm?id=667\&t=2

U.S. Energy Information Administration. (2013a). Annual Coal Report 2012. Retrieved August 1, 2014 from http://www.eia.gov/coal/annual/pdf/acr.pdf

U.S. Energy Information Administration. (2013b). Table 4.3. Existing Capacity by Energy Source, 2012 (Megawatts). In Electric Power Annual. Retrieved August 4, 2014 from http://www.eia.gov/electricity/annual/html/epa_04_03.html

U.S. Energy Information Administration. (2013c). Electricity Generating Capacity. Retrieved August 4, 2014 from http://www.eia.gov/electricity/capacity/

U.S. Environmental Protection Agency. (2014). Cross-State Air Pollution Rule (CSAPR) Retrieved August 5, 2014 from http://www.epa.gov/airtransport/CSAPR/

U.S. Office of Management and Budget. (2014). Summary Tables. Retrieved August 16, 2014 from http://www.whitehouse.gov/sites/default/files/omb/budget/fy2015/assets/tables.pdf

De Vries, B. J., Van Vuuren, D. P., \& Hoogwijk, M. M. (2007). Renewable energy sources: Their global potential for the first-half of the 21st century at a global level: An integrated approach. Energy policy, 35(4), 2590-2610.

Wei, M., Patadia, S., \& Kammen, D. (2010). Putting renewables and energy efficiency to work: how many jobs can the clean energy industry generate in the US? Energy Policy, 38 (2), 919-931.

Wheeler, S. M. (2008). State and municipal climate change plans: The first generation. Journal of the American Planning Association, 74(4), 481-496.

Wiser, Ryan H., Bolinger, Mark. (2013). 2012 Wind Technologies Market Report, Edited by Galen L. Barbose, Naïm Darghouth, Ben Hoen, Andrew D. Mills, Samantha Weaver, Kevin Porter, Michael Buckley, Sari Fink, Frank Oteri and Suzanne Tegen.

Yi, H. (2013). Clean energy policies and green jobs: An evaluation of green jobs in US metropolitan areas. Energy Policy, 56, 644-652. 
Appendix 1. Solar Photovoltaic Industry Employment in the U.S

\begin{tabular}{|c|c|c|c|c|c|}
\hline Title & $\begin{array}{c}\text { Skill } \\
\text { Level }\end{array}$ & Education & $\begin{array}{c}\text { Work } \\
\text { Experience } \\
\end{array}$ & $\begin{array}{l}\text { Hourly } \\
\text { Pay }\end{array}$ & $\begin{array}{c}\text { Annual } \\
\text { Pay }\end{array}$ \\
\hline \multicolumn{6}{|l|}{ Component Production } \\
\hline Quality Assurance Specialist & Middle & AA & 3 to 5 & $\$ 27.89$ & $\$ 58,020$ \\
\hline Process Control Technician & Middle & AA & 3 to 5 & $\$ 27.89$ & $\$ 58,020$ \\
\hline Industrial Engineer & Advanced & BA & $5+$ & $\$ 36.11$ & $\$ 75,110$ \\
\hline Environmental Engineer & Advanced & BA & $5+$ & $\$ 37.04$ & $\$ 77,040$ \\
\hline Mechanical Engineer & Advanced & BA & $5+$ & & $\$ 78,910$ \\
\hline Electrical Engineer & Advanced & BA & $5+$ & $\$ 32.58$ & $\$ 83,110$ \\
\hline $\begin{array}{l}\text { Computer Numerical Control (CNC) } \\
\text { Operator }\end{array}$ & Basic & HS & 1 to 3 & $\$ 17.26$ & $\$ 35,890$ \\
\hline Advanced Manufacturing Technician & Basic & HS + Certificate & 1 to 3 & $\$ 23.82$ & $\$ 49,550$ \\
\hline $\begin{array}{l}\text { Instrumentation and Electronics } \\
\text { Technician }\end{array}$ & Middle & HS + Certificate & 3 to 5 & $\$ 26.36$ & $\$ 54,820$ \\
\hline Materials Scientist & Advanced & $\mathrm{MS} / \mathrm{PhD}$ & $5+$ & $\$ 36.61$ & $\$ 80,300$ \\
\hline \multicolumn{6}{|l|}{ Installation \& Operations } \\
\hline Plumber with Solar Expertise & Middle & Apprentice-Level & 3 to 5 & $\$ 22.27$ & $\$ 46,320$ \\
\hline Electrician with Solar Expertise & Middle & $\begin{array}{l}\text { Apprentice-Level or } \\
\text { HS + Certificate }\end{array}$ & $5+$ & $\$ 21.98$ & $\$ 47,180$ \\
\hline $\begin{array}{l}\text { Solar PV Installer (residential/small } \\
\text { commercial) }\end{array}$ & Middle & $\begin{array}{l}\text { HS or Apprentice- } \\
\text { Level }\end{array}$ & 3 to 5 & $\$ 16.34$ & $\$ 33,980$ \\
\hline Solar Installation Contractor & Advanced & Journey-Level & $5+$ & $\$ 39.58$ & $\$ 82,330$ \\
\hline $\begin{array}{l}\text { Solar PV Technician } \\
\text { (commercial/utility) }\end{array}$ & Middle & Journey-Level & 3 to 5 & $\$ 29.94$ & $\$ 62,270$ \\
\hline Solar Installation Helper & Basic & None & 1 to 3 & $\$ 12.86$ & $\$ 26,760$ \\
\hline Mechanical Assembler & Basic & None & 1 to 3 & $\$ 13.77$ & $\$ 28,640$ \\
\hline \multicolumn{6}{|l|}{ Marketing Sales \& Permitting } \\
\hline Solar Sales Representative (Retail) & Middle & $\mathrm{AA}$ & 3 to 5 & $\$ 23.76$ & $\$ 49,410$ \\
\hline Solar Marketing Specialist & Middle & AA & 1 to 3 & $\$ 24.98$ & $\$ 51,960$ \\
\hline Building Inspector with Solar Expertise & Middle & $\begin{array}{l}\text { AA or Journey- } \\
\text { Level }\end{array}$ & 3 to 5 & $\$ 24.77$ & $\$ 51,530$ \\
\hline $\begin{array}{l}\text { Solar Project Developer/Sales } \\
\text { Representative (Wholesale) }\end{array}$ & Advanced & BA & $5+$ & $\$ 34.30$ & $\$ 71,340$ \\
\hline Solar Site Assessor & Basic & HS & 1 to 3 & $\$ 16.00$ & $\$ 33,280$ \\
\hline Code Official with Solar Expertise & Middle & HS + Certificate & 3 to 5 & $\$ 26.11$ & $\$ 54,320$ \\
\hline Lawyer with Solar Expertise & Advanced & J.D. & $5+$ & $\$ 54.44$ & $\$ 113,240$ \\
\hline Electrical Inspector with Solar Expertise & Middle & Journey-Level & 3 to 5 & $\$ 25.66$ & $\$ 53,372$ \\
\hline
\end{tabular}




\begin{tabular}{|l|l|l|l|l|l|}
\hline \multicolumn{2}{|l}{ System Design } \\
\hline Utility Interconnection Engineer & Middle & AA & $5+$ & $\$ 35.95$ & $\$ 75,065$ \\
\hline Residential PV System Designer & Middle & $\begin{array}{l}\text { AA or Journey- } \\
\text { Level }\end{array}$ & 3 to 5 & $\$ 26.36$ & $\$ 54,820$ \\
\hline Structural Engineer & Advanced & BA & $5+$ & $\$ 36.82$ & $\$ 76,590$ \\
\hline Solar Utility Procurement Specialist & Advanced & BA & 3 to 5 & $\$ 38.94$ & $\$ 81,000$ \\
\hline Power Systems Engineer & Advanced & BA & $5+$ & $\$ 41.05$ & $\$ 85,370$ \\
\hline Solar Energy Systems Designer & Advanced & BA & $5+$ & $\$ 43.06$ & $\$ 89,560$ \\
\hline Engineering Technician & Middle & HS + Certificate & 3 to 5 & $\$ 22.48$ & $\$ 46,760$ \\
\hline
\end{tabular}

Appendix 2. Solar Photovoltaic Industry Training Costs

\begin{tabular}{|c|c|c|c|c|c|}
\hline \multirow{2}{*}{ Title } & \multirow{2}{*}{ Training } & \multirow{2}{*}{$\begin{array}{l}\text { Training } \\
\text { Time }\end{array}$} & \multicolumn{2}{|c|}{ Cost } & \multirow{2}{*}{ Source } \\
\hline & & & $\begin{array}{l}\text { Low } \\
(\$)\end{array}$ & High (\$) & \\
\hline \multirow{3}{*}{$\begin{array}{l}\text { Quality Assurance } \\
\text { Specialist }\end{array}$} & $\begin{array}{l}\text { Associate's Degree in } \\
\text { Quality Assurance }\end{array}$ & 2 Years & $\$ 14,600$ & $\$ 18,060$ & $\begin{array}{l}\text { Lorain County Community } \\
\text { College; Columbus State } \\
\text { Community College }\end{array}$ \\
\hline & $\begin{array}{l}\text { ASQ Quality Inspector } \\
\text { Certification Preparation + } \\
\text { Certification }\end{array}$ & 2 Months & $\$ 576$ & $\$ 748$ & $\begin{array}{l}\text { ASQ (American Society } \\
\text { for Quality) }\end{array}$ \\
\hline & Total & $\begin{array}{r}2 \text { Years } 2 \\
\text { Months }\end{array}$ & $\$ 15,176$ & $\$ 18,808$ & \\
\hline $\begin{array}{l}\text { Process Control } \\
\text { Technician }\end{array}$ & $\begin{array}{l}\text { Associate's Degree Process } \\
\text { Technology }\end{array}$ & 2 Years & $\$ 9,280$ & $\$ 34,000$ & $\begin{array}{l}\text { Kanawha Valley } \\
\text { Community and Technical } \\
\text { College, WV; Jefferson } \\
\text { Community \& Technical } \\
\text { College, KY } \\
\end{array}$ \\
\hline $\begin{array}{l}\text { Industrial } \\
\text { Engineer }\end{array}$ & $\begin{array}{l}\text { University Degree in } \\
\text { Industrial Engineering }\end{array}$ & 4 Years & $\$ 30,048$ & $\$ 128,000$ & $\begin{array}{l}\text { West Virginia University; } \\
\text { University of Louisville; } \\
\text { Penn State }\end{array}$ \\
\hline $\begin{array}{l}\text { Environmental } \\
\text { Engineer }\end{array}$ & $\begin{array}{l}\text { University Degree in Civil } \\
\text { and Environmental } \\
\text { Engineering }\end{array}$ & 4 Years & $\$ 18,580$ & $\$ 136,000$ & $\begin{array}{l}\text { University of Wyoming; } \\
\text { West Virginia University; } \\
\text { University of Illinois at } \\
\text { Urbana-Champaign; Penn } \\
\text { State }\end{array}$ \\
\hline $\begin{array}{l}\text { Mechanical } \\
\text { Engineer }\end{array}$ & $\begin{array}{l}\text { University Degree in } \\
\text { Mechanical Engineering }\end{array}$ & 4 Years & $\$ 18,580$ & $\$ 136,000$ & $\begin{array}{l}\text { University of Wyoming; } \\
\text { West Virginia University; } \\
\text { University of Kentucky; } \\
\text { Penn State; University of } \\
\text { Illinois at Urbana- } \\
\text { Champaign } \\
\end{array}$ \\
\hline $\begin{array}{l}\text { Electrical } \\
\text { Engineer }\end{array}$ & $\begin{array}{l}\text { University Degree in } \\
\text { Electrical and Computer } \\
\text { Engineering }\end{array}$ & 4 Years & $\$ 18,580$ & $\$ 136,000$ & $\begin{array}{l}\text { University of Wyoming; } \\
\text { West Virginia University; } \\
\text { University of Kentucky; } \\
\text { Penn State; University of } \\
\text { Illinois at Urbana- } \\
\text { Champaign }\end{array}$ \\
\hline
\end{tabular}




\begin{tabular}{|c|c|c|c|c|c|}
\hline $\begin{array}{c}\text { Computer } \\
\text { Numerical } \\
\text { Control (CNC) } \\
\text { Operator } \\
\end{array}$ & $\begin{array}{l}\text { Certificate in Machine } \\
\text { Technology }\end{array}$ & 1 Year & $\$ 3,012$ & $\$ 6,996$ & $\begin{array}{l}\text { Sheridan College Northern } \\
\text { Wyoming; New River } \\
\text { Community and Technical } \\
\text { College West Virginia }\end{array}$ \\
\hline $\begin{array}{l}\text { Advanced } \\
\text { Manufacturing } \\
\text { Technician }\end{array}$ & $\begin{array}{l}\text { Associates or Certificate in } \\
\text { Manufacturing } \\
\text { Technology or } \\
\text { Mechatronics }\end{array}$ & $\begin{array}{l}1 \text { to } 2 \\
\text { Years }\end{array}$ & $\$ 2,448$ & $\$ 17,520$ & $\begin{array}{l}\text { Casper College WY; West } \\
\text { Virginia Northern } \\
\text { Community College }\end{array}$ \\
\hline $\begin{array}{l}\text { Instrumentation } \\
\text { and Electronics } \\
\text { Technician }\end{array}$ & $\begin{array}{l}\text { Associates or Certificate in } \\
\text { Manufacturing } \\
\text { Technology or } \\
\text { Mechatronics } \\
\end{array}$ & $\begin{array}{l}1 \text { to } 2 \\
\text { Years } \\
\end{array}$ & $\$ 2,448$ & $\$ 17,520$ & $\begin{array}{l}\text { Casper College WY; West } \\
\text { Virginia Northern } \\
\text { Community College } \\
\end{array}$ \\
\hline \multirow{3}{*}{$\begin{array}{l}\text { Materials } \\
\text { Scientist }\end{array}$} & $\begin{array}{l}\text { Undergraduate degree in } \\
\text { material science } \\
\text { engineering }\end{array}$ & 4 Years & $\$ 42,400$ & $\$ 136,000$ & $\begin{array}{l}\text { University of Kentucky; } \\
\text { Penn State; University of } \\
\text { Illinois at Urbana- } \\
\text { Champaign }\end{array}$ \\
\hline & $\begin{array}{l}\text { MS or MEng in energy or } \\
\text { semiconductor material } \\
\text { science. }\end{array}$ & $\begin{array}{l}1 \text { to } 2 \\
\text { Years } \\
\end{array}$ & $\$ 7,956$ & $\$ 52,432$ & $\begin{array}{l}\text { University of Wyoming; } \\
\text { University of Virginia; } \\
\text { University of Kentucky; } \\
\text { Penn State; University of } \\
\text { Illinois }\end{array}$ \\
\hline & Total & $\begin{array}{l}5 \text { to } 6 \\
\text { Years } \\
\end{array}$ & $\$ 50,356$ & $\$ 188,432$ & \\
\hline \multirow{4}{*}{$\begin{array}{l}\text { Plumber with } \\
\text { Solar Expertise }\end{array}$} & $\begin{array}{l}\text { SEI Residential and } \\
\text { Commercial Photovoltaic } \\
\text { Systems Certificate }\end{array}$ & $\begin{array}{r}3.2 \\
\text { Months }\end{array}$ & $\$ 3,795$ & $\$ 3,795$ & Solar Energy International \\
\hline & $\begin{array}{l}\text { Minimum Exam } \\
\text { Prerequisite Experience: } 3 \\
\text { PV Installs with a } \\
\text { Decision Making Role } \\
\end{array}$ & $\begin{array}{r}\sim 3 \\
\text { Months } \\
\end{array}$ & & & \\
\hline & $\begin{array}{l}\text { NABCEP PV Installation } \\
\text { Professional Exam and } \\
\text { Certification }\end{array}$ & 3 Months & $\$ 500$ & $\$ 500$ & $\begin{array}{l}\text { North American Board of } \\
\text { Certified Energy } \\
\text { Practitioners (NABCEP) }\end{array}$ \\
\hline & Total & 9 Months & $\$ 4,295$ & $\$ 4,295$ & \\
\hline \multirow{4}{*}{$\begin{array}{l}\text { Electrician with } \\
\text { Solar Expertise }\end{array}$} & $\begin{array}{l}\text { SEI Residential and } \\
\text { Commercial Photovoltaic } \\
\text { Systems Certificate }\end{array}$ & $\begin{array}{r}3.2 \\
\text { Months }\end{array}$ & $\$ 3,795$ & $\$ 3,795$ & Solar Energy International \\
\hline & $\begin{array}{l}\text { Minimum Exam } \\
\text { Prerequisite Experience: } 3 \\
\text { PV Installs with a } \\
\text { Decision Making Role }\end{array}$ & $\begin{array}{r}\sim 3 \\
\text { Months } \\
\end{array}$ & & & \\
\hline & $\begin{array}{l}\text { NABCEP PV Installation } \\
\text { Professional Exam and } \\
\text { Certification }\end{array}$ & 3 Months & $\$ 500$ & $\$ 500$ & $\begin{array}{l}\text { North American Board of } \\
\text { Certified Energy } \\
\text { Practitioners (NABCEP) }\end{array}$ \\
\hline & Total & 9 Months & $\$ 4,295$ & $\$ 4,295$ & \\
\hline \multirow{2}{*}{$\begin{array}{l}\text { Solar PV Installer } \\
\text { (residential/small } \\
\text { commercial) }\end{array}$} & $\begin{array}{l}\text { SEI Residential and } \\
\text { Commercial Photovoltaic } \\
\text { Systems Certificate }\end{array}$ & $\begin{array}{r}3.2 \\
\text { Months }\end{array}$ & $\$ 3,795$ & $\$ 3,795$ & Solar Energy International \\
\hline & $\begin{array}{l}\text { Minimum Exam } \\
\text { Prerequisite Experience: } 3 \\
\text { PV Installs with a } \\
\text { Decision Making Role } \\
\end{array}$ & $\begin{array}{r}\sim 3 \\
\text { Months } \\
\end{array}$ & & & \\
\hline
\end{tabular}




\begin{tabular}{|c|c|c|c|c|c|}
\hline & $\begin{array}{l}\text { NABCEP PV Installation } \\
\text { Professional Certification }\end{array}$ & 3 Months & $\$ 500$ & $\$ 500$ & $\begin{array}{l}\text { North American Board of } \\
\text { Certified Energy } \\
\text { Practitioners (NABCEP) }\end{array}$ \\
\hline & Total & 9 Months & $\$ 4,295$ & $\$ 4,295$ & \\
\hline \multirow{7}{*}{$\begin{array}{l}\text { Solar Installation } \\
\text { Contractor }\end{array}$} & $\begin{array}{l}\text { IECRM Evening Trade } \\
\text { School Classes while } \\
\text { working as an Apprentice } \\
\text { Electrician }(8,000 \mathrm{hrs})\end{array}$ & 4 Years & $\$ 4,688$ & $\$ 6,688$ & $\begin{array}{l}\text { Independent Electrical } \\
\text { Contractors Rocky } \\
\text { Mountain (IECRM) }\end{array}$ \\
\hline & $\begin{array}{l}\text { Apprentice + Journeyman } \\
\text { Electrician License } \\
\text { Registration \& Exam Fees }\end{array}$ & & $\$ 230$ & $\$ 435$ & $\begin{array}{l}\text { Wyoming State Fire } \\
\text { Marshal; West Virginia } \\
\text { Fire Commission }\end{array}$ \\
\hline & $\begin{array}{l}4 \text { Years as a Journey Level } \\
\text { Electrician ( } 8,000 \mathrm{hrs})\end{array}$ & 4 Years & & & \\
\hline & $\begin{array}{l}\text { Master Electrician License } \\
\text { Exam }\end{array}$ & & $\$ 75$ & $\$ 200$ & $\begin{array}{l}\text { Wyoming State Fire } \\
\text { Marshal; West Virginia } \\
\text { Fire Commission }\end{array}$ \\
\hline & $\begin{array}{l}\text { SEI Residential and } \\
\text { Commercial Photovoltaic } \\
\text { Systems Certificate }\end{array}$ & $\begin{array}{r}3.2 \\
\text { Months } \\
\end{array}$ & $\$ 3,795$ & $\$ 3,795$ & Solar Energy International \\
\hline & $\begin{array}{l}\text { NABCEP PV Installation } \\
\text { Professional Exam and } \\
\text { Certification }\end{array}$ & 3 Months & $\$ 500$ & $\$ 500$ & $\begin{array}{l}\text { North American Board of } \\
\text { Certified Energy } \\
\text { Practitioners (NABCEP) }\end{array}$ \\
\hline & Total & $\begin{array}{l}8 \text { to } 9 \\
\text { Years } \\
\end{array}$ & $\$ 9,288$ & $\$ 11,618$ & \\
\hline \multirow{5}{*}{$\begin{array}{c}\text { Solar PV } \\
\text { Technician } \\
\text { (commercial/utilit } \\
\text { y) }\end{array}$} & $\begin{array}{l}\text { IECRM Evening Trade } \\
\text { School Classes while } \\
\text { working as an Apprentice } \\
\text { Electrician ( } 8,000 \text { hrs) }\end{array}$ & 4 Years & $\$ 4,688$ & $\$ 6,688$ & $\begin{array}{l}\text { Independent Electrical } \\
\text { Contractors Rocky } \\
\text { Mountain (IECRM) }\end{array}$ \\
\hline & $\begin{array}{l}\text { Apprentice + Journeyman } \\
\text { Electrician License } \\
\text { Registration \& Exam Fees }\end{array}$ & & $\$ 230$ & $\$ 435$ & $\begin{array}{l}\text { Wyoming State Fire } \\
\text { Marshal; West Virginia } \\
\text { Fire Commission }\end{array}$ \\
\hline & $\begin{array}{l}\text { SEI Residential and } \\
\text { Commercial Photovoltaic } \\
\text { Systems Certificate } \\
\end{array}$ & $\begin{array}{r}3.2 \\
\text { Months } \\
\end{array}$ & $\$ 3,795$ & $\$ 3,795$ & Solar Energy International \\
\hline & $\begin{array}{l}\text { NABCEP PV Installation } \\
\text { Professional Exam and } \\
\text { Certification }\end{array}$ & 3 Months & $\$ 500$ & $\$ 500$ & $\begin{array}{l}\text { North American Board of } \\
\text { Certified Energy } \\
\text { Practitioners (NABCEP) }\end{array}$ \\
\hline & Total & $\begin{array}{l}4 \text { to } 5 \\
\text { years } \\
\end{array}$ & $\$ 9,213$ & $\$ 11,418$ & \\
\hline $\begin{array}{l}\text { Solar Installation } \\
\text { Helper }\end{array}$ & $\begin{array}{l}\text { SEI Online Courses + } \\
\text { NABCEP Entry Level } \\
\text { Certification Package } \\
\end{array}$ & 3 months & $\$ 1,295$ & $\$ 1,295$ & Solar Energy International \\
\hline $\begin{array}{l}\text { Mechanical } \\
\text { Assembler }\end{array}$ & $\begin{array}{l}\text { SEI Online Courses }+ \\
\text { NABCEP Entry Level } \\
\text { Certification Package } \\
\end{array}$ & 3 months & $\$ 1,295$ & $\$ 1,295$ & Solar Energy International \\
\hline \multirow[t]{2}{*}{$\begin{array}{c}\text { Solar Sales } \\
\text { Representative } \\
\text { (Retail) }\end{array}$} & Associates in Marketing & 2 Years & $\$ 4,800$ & $\$ 34,254$ & $\begin{array}{l}\text { Western Wyoming } \\
\text { Community College; } \\
\text { Bluegrass Community and } \\
\text { Technical College, KY; } \\
\text { Bucks County Community } \\
\text { College, PA }\end{array}$ \\
\hline & $\begin{array}{l}\text { SEI Solar Business and } \\
\text { Technical Sales Certificate }\end{array}$ & $\begin{array}{r}3.2 \\
\text { Months } \\
\end{array}$ & $\$ 3,095$ & $\$ 3,495$ & Solar Energy International \\
\hline
\end{tabular}




\begin{tabular}{|c|c|c|c|c|c|}
\hline & $\begin{array}{l}\text { NABCEP Entry Level } \\
\text { Certification }\end{array}$ & 1 Week & $\$ 120$ & $\$ 120$ & $\begin{array}{l}\text { Solar Energy International; } \\
\text { North American Board of } \\
\text { Certified Energy } \\
\text { Practitioners (NABCEP) }\end{array}$ \\
\hline & $\begin{array}{l}\text { Minimum Exam } \\
\text { Prerequisite Experience: } \\
\text { 4/8 PV system sales }\end{array}$ & 4 Months & & & \\
\hline & $\begin{array}{l}\text { NABCEP NABCEP PV } \\
\text { Technical Sales } \\
\text { Certification }\end{array}$ & 3 Months & $\$ 500$ & $\$ 500$ & $\begin{array}{l}\text { North American Board of } \\
\text { Certified Energy } \\
\text { Practitioners (NABCEP) }\end{array}$ \\
\hline & Total & $\begin{array}{r}\sim 3 \\
\text { Years } \\
\end{array}$ & $\$ 8,515$ & $\$ 38,369$ & \\
\hline \multirow{6}{*}{$\begin{array}{l}\text { Solar Marketing } \\
\text { Specialist }\end{array}$} & Associates in Marketing & 2 Years & $\$ 4,800$ & $\$ 34,254$ & $\begin{array}{l}\text { Western Wyoming } \\
\text { Community College; } \\
\text { Bluegrass Community and } \\
\text { Technical College, KY; } \\
\text { Bucks County Community } \\
\text { College, PA }\end{array}$ \\
\hline & $\begin{array}{l}\text { SEI Solar Business and } \\
\text { Technical Sales Certificate }\end{array}$ & $\begin{array}{r}3.2 \\
\text { Months } \\
\end{array}$ & $\$ 3,095$ & $\$ 3,495$ & Solar Energy International \\
\hline & $\begin{array}{l}\text { NABCEP Entry Level } \\
\text { Certification }\end{array}$ & 1 Week & $\$ 120$ & $\$ 120$ & $\begin{array}{l}\text { Solar Energy International; } \\
\text { North American Board of } \\
\text { Certified Energy } \\
\text { Practitioners (NABCEP) }\end{array}$ \\
\hline & $\begin{array}{l}\text { Minimum Exam } \\
\text { Prerequisite Experience: } \\
\text { 4/8 PV system sales }\end{array}$ & 4 Months & & & \\
\hline & $\begin{array}{l}\text { NABCEP NABCEP PV } \\
\text { Technical Sales } \\
\text { Certification }\end{array}$ & 3 Months & $\$ 500$ & $\$ 500$ & $\begin{array}{l}\text { North American Board of } \\
\text { Certified Energy } \\
\text { Practitioners (NABCEP) }\end{array}$ \\
\hline & Total & $\begin{array}{r}\sim 3 \\
\text { Years } \\
\end{array}$ & $\$ 8,515$ & $\$ 38,369$ & \\
\hline \multirow{4}{*}{$\begin{array}{l}\text { Building } \\
\text { Inspector with } \\
\text { Solar Expertise }\end{array}$} & $\begin{array}{l}\text { SEI Residential and } \\
\text { Commercial Photovoltaic } \\
\text { Systems Certificate }\end{array}$ & $\begin{array}{r}3.2 \\
\text { Months } \\
\end{array}$ & $\$ 3,795$ & $\$ 3,795$ & Solar Energy International \\
\hline & $\begin{array}{l}\text { Minimum Exam } \\
\text { Prerequisite Experience: } 3 \\
\text { PV Installs with a } \\
\text { Decision Making Role } \\
\end{array}$ & $\begin{array}{r}\sim 3 \\
\text { Months } \\
\end{array}$ & & & \\
\hline & $\begin{array}{l}\text { NABCEP PV Installation } \\
\text { Professional Exam and } \\
\text { Certification }\end{array}$ & 3 Months & $\$ 500$ & $\$ 500$ & $\begin{array}{l}\text { North American Board of } \\
\text { Certified Energy } \\
\text { Practitioners (NABCEP) }\end{array}$ \\
\hline & Total & 9 Months & $\$ 4,295$ & $\$ 4,295$ & \\
\hline \multirow[t]{2}{*}{$\begin{array}{c}\text { Solar Project } \\
\text { Developer/Sales } \\
\text { Representative } \\
\text { (Wholesale) }\end{array}$} & $\begin{array}{l}\text { University Degree in } \\
\text { Electrical and Computer } \\
\text { Engineering or Civil } \\
\text { Engineering }\end{array}$ & 4 Years & $\$ 18,580$ & $\$ 136,000$ & $\begin{array}{l}\text { University of Wyoming; } \\
\text { West Virginia University; } \\
\text { University of Kentucky; } \\
\text { Penn State; University of } \\
\text { Illinois at Urbana- } \\
\text { Champaign }\end{array}$ \\
\hline & $\begin{array}{l}\text { SEI Solar Business and } \\
\text { Technical Sales Certificate }\end{array}$ & $\begin{array}{r}3.2 \\
\text { Months }\end{array}$ & $\$ 3,095$ & $\$ 3,495$ & Solar Energy International \\
\hline
\end{tabular}




\begin{tabular}{|c|c|c|c|c|c|}
\hline & $\begin{array}{l}\text { Minimum Exam } \\
\text { Prerequisite Experience: } 4 \\
\text { PV system sales }\end{array}$ & 2 Months & & & \\
\hline & $\begin{array}{l}\text { NABCEP PV Technical } \\
\text { Sales Certification }\end{array}$ & 3 Months & $\$ 500$ & $\$ 500$ & $\begin{array}{l}\text { North American Board of } \\
\text { Certified Energy } \\
\text { Practitioners (NABCEP) }\end{array}$ \\
\hline & Total & $\begin{array}{r}4 \text { Years } \\
\text { \& } 9 \\
\text { Months }\end{array}$ & $\$ 22,175$ & $\$ 139,995$ & \\
\hline $\begin{array}{l}\text { Solar Site } \\
\text { Assessor }\end{array}$ & $\begin{array}{l}3 \text { months SEI Online } \\
\text { Courses + NABCEP Entry } \\
\text { Level Certification }\end{array}$ & 3 Months & $\$ 1,295$ & $\$ 1,295$ & Solar Energy International \\
\hline \multirow{4}{*}{$\begin{array}{l}\text { Code Official } \\
\text { with Solar } \\
\text { Expertise }\end{array}$} & $\begin{array}{l}\text { Associate in Building } \\
\text { Inspection and Code } \\
\text { Enforcement Technology }\end{array}$ & 2 Years & $\$ 9,996$ & $\$ 13,736$ & $\begin{array}{l}\text { St. Louis Community } \\
\text { College }\end{array}$ \\
\hline & $\begin{array}{l}\text { ICC Code Inspector } \\
\text { Certificates: Residential \& } \\
\text { Commercial Electrical } \\
\text { Inspector }\end{array}$ & $\begin{array}{r}\sim 3 \\
\text { Months } \\
\end{array}$ & $\$ 646$ & $\$ 646$ & International Code Council \\
\hline & $\begin{array}{l}\text { SEI Online Courses + } \\
\text { NABCEP Entry Level } \\
\text { Certification Package }\end{array}$ & 3 Months & $\$ 1,295$ & $\$ 1,295$ & Solar Energy International \\
\hline & Total & 2.5 Years & $\$ 11,937$ & $\$ 15,677$ & \\
\hline $\begin{array}{c}\text { Lawyer with Solar } \\
\text { Expertise }\end{array}$ & Certificate in Energy Law & 0.5 Year & $\$ 23,055$ & $\$ 23,055$ & Vermont Law School \\
\hline \multirow{4}{*}{$\begin{array}{c}\text { Electrical } \\
\text { Inspector with } \\
\text { Solar Expertise }\end{array}$} & $\begin{array}{l}\text { SEI Residential and } \\
\text { Commercial Photovoltaic } \\
\text { Systems Certificate }\end{array}$ & $\begin{array}{r}3.2 \\
\text { Months } \\
\end{array}$ & $\$ 3,795$ & $\$ 3,795$ & Solar Energy International \\
\hline & $\begin{array}{l}\text { Minimum Exam } \\
\text { Prerequisite Experience: } 3 \\
\text { PV Installs with a } \\
\text { Decision Making Role }\end{array}$ & $\begin{array}{r}\sim 3 \\
\text { Months }\end{array}$ & & & \\
\hline & $\begin{array}{l}\text { NABCEP PV Installation } \\
\text { Professional Exam and } \\
\text { Certification }\end{array}$ & 3 Months & $\$ 500$ & $\$ 500$ & $\begin{array}{l}\text { North American Board of } \\
\text { Certified Energy } \\
\text { Practitioners (NABCEP) }\end{array}$ \\
\hline & Total & 9 Months & $\$ 4,295$ & $\$ 4,295$ & \\
\hline $\begin{array}{l}\text { Utility } \\
\text { Interconnection } \\
\text { Engineer }\end{array}$ & $\begin{array}{l}\text { Associates in Electric } \\
\text { Distribution Engineering } \\
\text { Technology then transfer } \\
\text { or University Degree in } \\
\text { Electrical and Computer } \\
\text { Engineering or Civil } \\
\text { Engineering }\end{array}$ & 4 Years & $\$ 17,870$ & $\$ 136,000$ & $\begin{array}{l}\text { Blue Ridge Community } \\
\text { and Technical College; } \\
\text { University of Wyoming; } \\
\text { West Virginia University; } \\
\text { University of Kentucky; } \\
\text { Penn State; University of } \\
\text { Illinois at Urbana- } \\
\text { Champaign }\end{array}$ \\
\hline $\begin{array}{l}\text { Residential PV } \\
\text { System Designer }\end{array}$ & $\begin{array}{l}\text { Associates in Electrical } \\
\text { Engineering/Technology }\end{array}$ & 2 Years & $\$ 6,096$ & $\$ 31,140$ & $\begin{array}{l}\text { Southern West Virginia } \\
\text { Community and Technical } \\
\text { College; Bluegrass } \\
\text { Community and Technical } \\
\text { College, KY; } \\
\text { Northampton Community } \\
\text { College, PA }\end{array}$ \\
\hline
\end{tabular}




\begin{tabular}{|c|c|c|c|c|c|}
\hline & $\begin{array}{l}\text { SEI Residential and } \\
\text { Commercial Photovoltaic } \\
\text { Systems Certificate }\end{array}$ & $\begin{array}{r}3.2 \\
\text { Months } \\
\end{array}$ & $\$ 3,795$ & $\$ 3,795$ & Solar Energy International \\
\hline & $\begin{array}{l}\text { Minimum Exam } \\
\text { Prerequisite Experience } 3 \\
\text { PV Installs } \\
\end{array}$ & & & & \\
\hline & $\begin{array}{l}\text { NABCEP PV Installation } \\
\text { Professional Certification }\end{array}$ & 3 Months & $\$ 500$ & $\$ 500$ & $\begin{array}{l}\text { North American Board of } \\
\text { Certified Energy } \\
\text { Practitioners (NABCEP) }\end{array}$ \\
\hline & Total & 2.5 Years & $\$ 10,391$ & $\$ 35,435$ & \\
\hline \multirow{3}{*}{$\begin{array}{l}\text { Structural } \\
\text { Engineer }\end{array}$} & $\begin{array}{l}\text { University Degree in Civil } \\
\text { Engineering with } \\
\text { concentration in structures }\end{array}$ & 4 Years & $\$ 18,580$ & $\$ 136,000$ & $\begin{array}{l}\text { University of Wyoming; } \\
\text { West Virginia University; } \\
\text { University of Kentucky; } \\
\text { Penn State; University of } \\
\text { Illinois at Urbana- } \\
\text { Champaign }\end{array}$ \\
\hline & $\begin{array}{l}\text { Master of Engineering } \\
\text { Degree in Structural } \\
\text { Engineer }\end{array}$ & 1 Year & $\$ 7,956$ & $\$ 33,386$ & $\begin{array}{l}\text { University of Wyoming; } \\
\text { West Virginia University; } \\
\text { University of Kentucky; } \\
\text { Penn State; University of } \\
\text { Illinois at Urbana- } \\
\text { Champaign }\end{array}$ \\
\hline & Total & 5 Years & $\$ 26,536$ & $\$ 169,386$ & \\
\hline $\begin{array}{l}\text { Solar Utility } \\
\text { Procurement } \\
\text { Specialist }\end{array}$ & $\begin{array}{l}\text { University Degree in } \\
\text { Electrical and Computer } \\
\text { Engineering }\end{array}$ & 4 Years & $\$ 18,580$ & $\$ 136,000$ & $\begin{array}{l}\text { University of Wyoming; } \\
\text { West Virginia University; } \\
\text { University of Kentucky; } \\
\text { Penn State; University of } \\
\text { Illinois at Urbana- } \\
\text { Champaign }\end{array}$ \\
\hline $\begin{array}{l}\text { Power Systems } \\
\text { Engineer }\end{array}$ & $\begin{array}{l}\text { University Degree in } \\
\text { Electrical and Computer } \\
\text { Engineering with } \\
\text { concentrations in power } \\
\text { engineering }\end{array}$ & 4 Years & $\$ 18,580$ & $\$ 136,000$ & $\begin{array}{l}\text { University of Wyoming; } \\
\text { West Virginia University; } \\
\text { University of Kentucky; } \\
\text { Penn State; University of } \\
\text { Illinois at Urbana- } \\
\text { Champaign }\end{array}$ \\
\hline \multirow{5}{*}{$\begin{array}{c}\text { Solar Energy } \\
\text { Systems Designer }\end{array}$} & $\begin{array}{l}\text { University Degree in } \\
\text { Electrical and Computer } \\
\text { Engineering or Civil } \\
\text { Engineering }\end{array}$ & 4 Years & $\$ 18,580$ & $\$ 136,000$ & $\begin{array}{l}\text { University of Wyoming; } \\
\text { West Virginia University; } \\
\text { University of Kentucky; } \\
\text { Penn State; University of } \\
\text { Illinois at Urbana- } \\
\text { Champaign }\end{array}$ \\
\hline & $\begin{array}{l}\text { SEI Residential and } \\
\text { Commercial Photovoltaic } \\
\text { Systems Certificate }\end{array}$ & $\begin{array}{r}3.2 \\
\text { Months } \\
\end{array}$ & $\$ 3,795$ & $\$ 3,795$ & Solar Energy International \\
\hline & $\begin{array}{l}\text { Minimum Exam } \\
\text { Prerequisite Experience } 3 \\
\text { PV Installs }\end{array}$ & $\begin{array}{r}\sim 3 \\
\text { Months } \\
\end{array}$ & & & \\
\hline & $\begin{array}{l}\text { NABCEP PV Installation } \\
\text { Professional Certification }\end{array}$ & 3 Months & $\$ 500$ & $\$ 500$ & $\begin{array}{l}\text { North American Board of } \\
\text { Certified Energy } \\
\text { Practitioners (NABCEP) }\end{array}$ \\
\hline & Total & $\begin{array}{r}\sim 5 \\
\text { Years } \\
\end{array}$ & $\$ 22,875$ & $\$ 140,295$ & \\
\hline
\end{tabular}




\begin{tabular}{c|l|l|l|l|}
$\begin{array}{c}\text { Engineering } \\
\text { Technician }\end{array}$ & & & & $\begin{array}{l}\text { Laramie County } \\
\text { Community College; West } \\
\text { Kentucky Community and } \\
\text { Technical College; Butler }\end{array}$ \\
& $\begin{array}{l}\text { Certificate or Associate in } \\
\text { Engineering Technology }\end{array}$ & $1-2$ Year & $\$ 7,868$ & $\begin{array}{l}\text { County Community } \\
\text { College }\end{array}$ \\
\hline
\end{tabular}

\section{Appendix 3. Employment Transitions Between Coal Mining and Solar Photovoltaic Industries}

\begin{tabular}{|c|c|c|c|c|c|c|c|c|}
\hline $\begin{array}{l}\text { Train } \\
\text { ing }\end{array}$ & $\begin{array}{l}\text { Occupation } \\
\text { Title }\end{array}$ & $\begin{array}{l}\text { Emplo } \\
\text { yees }\end{array}$ & $\begin{array}{c}\text { Median } \\
\text { hourly } \\
\text { wage }\end{array}$ & $\begin{array}{c}\text { Annual } \\
\text { median } \\
\text { wage }\end{array}$ & Closest PV Job & $\begin{array}{c}\text { Median } \\
\text { hourly } \\
\text { wage }\end{array}$ & $\begin{array}{c}\text { Annual } \\
\text { median } \\
\text { wage }\end{array}$ & $\begin{array}{c}\Delta \\
\text { Wage } \\
\%\end{array}$ \\
\hline $\mathrm{Y}$ & $\begin{array}{l}\text { Mining and } \\
\text { Geological } \\
\text { Engineers, } \\
\text { Including } \\
\text { Mining Safety } \\
\text { Engineers }\end{array}$ & 810 & $\$ 40.45$ & $\$ 84,136$ & Structural Engineer & $\$ 36.82$ & $\$ 76,590$ & $-9 \%$ \\
\hline $\mathrm{Y}$ & $\begin{array}{l}\text { Explosives } \\
\text { Workers, } \\
\text { Ordnance } \\
\text { Handling } \\
\text { Experts, and } \\
\text { Blasters }\end{array}$ & 360 & $\$ 26.91$ & $\$ 55,973$ & $\begin{array}{l}\text { Solar PV Technician } \\
\text { (commercial/utility) }\end{array}$ & $\$ 29.94$ & $\$ 62,270$ & $11 \%$ \\
\hline $\mathrm{Y}$ & $\begin{array}{l}\text { Continuous } \\
\text { Mining Machine } \\
\text { Operators }\end{array}$ & 4,880 & $\$ 24.86$ & $\$ 51,709$ & $\begin{array}{l}\text { Instrumentation and } \\
\text { Electronics } \\
\text { Technician }\end{array}$ & 26.36 & $\$ 54,820$ & $6 \%$ \\
\hline $\mathrm{Y}$ & $\begin{array}{l}\text { Mine Cutting } \\
\text { and Channeling } \\
\text { Machine } \\
\text { Operators }\end{array}$ & 2,630 & $\$ 26.07$ & $\$ 54,226$ & $\begin{array}{l}\text { Advanced } \\
\text { Manufacturing } \\
\text { Technician }\end{array}$ & .82 & & $-9 \%$ \\
\hline $\mathrm{Y}$ & $\begin{array}{l}\text { Mining Machine } \\
\text { Operators, All } \\
\text { Other }\end{array}$ & 640 & $\$ 25.90$ & $\$ 53,872$ & $\begin{array}{l}\text { Advanced } \\
\text { Manufacturing } \\
\text { Technician }\end{array}$ & .82 & $\$ 4$ & $-8 \%$ \\
\hline $\mathrm{Y}$ & $\begin{array}{l}\text { Roof Bolters, } \\
\text { Mining }\end{array}$ & 5,620 & $\$ 26.35$ & $\$ 54,808$ & $\begin{array}{l}\text { Quality Assurance } \\
\text { Specialist }\end{array}$ & $\$ 27.89$ & $\$ 58,020$ & $6 \%$ \\
\hline $\mathrm{Y}$ & $\begin{array}{l}\text { Extraction } \\
\text { Workers, All } \\
\text { Other }\end{array}$ & 1,300 & $\$ 21.75$ & $\$ 45,240$ & $\begin{array}{l}\text { Advanced } \\
\text { Manufacturing } \\
\text { Technician }\end{array}$ & $\$ 23.82$ & 550 & $10 \%$ \\
\hline $\mathrm{Y}$ & $\begin{array}{l}\text { Conveyor } \\
\text { Operators and } \\
\text { Tenders }\end{array}$ & 1,390 & $\$ 25.75$ & $\$ 53,560$ & $\begin{array}{l}\text { Instrumentation and } \\
\text { Electronics } \\
\text { Technician }\end{array}$ & $\$ 26.36$ & $\$ 54,820$ & $2 \%$ \\
\hline $\mathrm{Y}$ & $\begin{array}{l}\text { Excavating and } \\
\text { Loading } \\
\text { Machine and } \\
\text { Dragline } \\
\text { Operators } \\
\end{array}$ & 4,720 & $\$ 22.22$ & $\$ 46,218$ & $\begin{array}{l}\text { Advanced } \\
\text { Manufacturing } \\
\text { Technician } \\
\end{array}$ & $\$ 23.82$ & $\$ 49,550$ & $7 \%$ \\
\hline 1 & $\begin{array}{l}\text { Loading } \\
\text { Machine } \\
\text { Operators, }\end{array}$ & 2,320 & $\$ 24.85$ & $\$ 51,688$ & $\begin{array}{l}\text { Advanced } \\
\text { Manufacturing } \\
\text { Technician }\end{array}$ & $\$ 23.82$ & $\$ 49,550$ & $-4 \%$ \\
\hline
\end{tabular}


Preprint to be published: Edward P. Louie and Joshua M. Pearce. Retraining Investment for U.S. Transition from Coal to Solar Photovoltaic Employment. Energy Economics. (2016). doi:10.1016/j.eneco.2016.05.016

\begin{tabular}{|c|c|c|c|c|c|c|c|c|}
\hline & $\begin{array}{l}\text { Underground } \\
\text { Mining }\end{array}$ & & & & & & & \\
\hline $\mathrm{Y}$ & $\begin{array}{l}\text { Hoist and Winch } \\
\text { Operators }\end{array}$ & 80 & $\$ 20.79$ & $\$ 43,243$ & $\begin{array}{l}\text { Advanced } \\
\text { Manufacturing } \\
\text { Technician }\end{array}$ & $\$ 23.82$ & $\$ 49,550$ & $15 \%$ \\
\hline $\mathrm{Y}$ & $\begin{array}{l}\text { Mine Shuttle Car } \\
\text { Operators }\end{array}$ & 2,600 & $\$ 25.47$ & $\$ 52,978$ & $\begin{array}{l}\text { Mechanical } \\
\text { Assembler }\end{array}$ & $\$ 13.77$ & $\$ 28,640$ & $-46 \%$ \\
\hline $\mathrm{N}$ & $\begin{array}{l}\text { Administrative } \\
\text { Services } \\
\text { Managers } \\
\end{array}$ & 100 & $\$ 49.58$ & $\$ 103,126$ & $\begin{array}{l}\text { Solar Marketing } \\
\text { Specialist }\end{array}$ & $\$ 24.98$ & $\$ 51,960$ & $-50 \%$ \\
\hline $\mathrm{N}$ & $\begin{array}{l}\text { Financial } \\
\text { Managers }\end{array}$ & 70 & $\$ 55.13$ & $\$ 114,670$ & $\begin{array}{l}\text { Solar Project } \\
\text { Developer/Sales } \\
\text { Representative } \\
\text { (Wholesale) }\end{array}$ & $\$ 34.30$ & $\$ 71,340$ & $-38 \%$ \\
\hline $\mathrm{N}$ & $\begin{array}{l}\text { Industrial } \\
\text { Production } \\
\text { Managers }\end{array}$ & 290 & $\$ 50.74$ & $\$ 105,539$ & Industrial Engineer & $\$ 36.11$ & $\$ 75,110$ & $-29 \%$ \\
\hline $\mathrm{N}$ & $\begin{array}{l}\text { Purchasing } \\
\text { Managers }\end{array}$ & 50 & $\$ 43.21$ & $\$ 89,877$ & $\begin{array}{l}\text { Solar Utility } \\
\text { Procurement } \\
\text { Specialist } \\
\end{array}$ & $\$ 38.94$ & $\$ 81,000$ & $-10 \%$ \\
\hline $\mathrm{N}$ & $\begin{array}{l}\text { Construction } \\
\text { Managers }\end{array}$ & 170 & $\$ 48.33$ & $\$ 100,526$ & $\begin{array}{l}\text { Solar Installation } \\
\text { Contractor }\end{array}$ & $\$ 39.58$ & $\$ 82,330$ & $-18 \%$ \\
\hline $\mathrm{N}$ & $\begin{array}{l}\text { Architectural and } \\
\text { Engineering } \\
\text { Managers }\end{array}$ & 120 & $\$ 57.77$ & $\$ 120,162$ & $\begin{array}{l}\text { Solar Energy } \\
\text { Systems Designer }\end{array}$ & $\$ 43.06$ & $\$ 89,560$ & $-25 \%$ \\
\hline $\mathrm{N}$ & $\begin{array}{l}\text { Managers, All } \\
\text { Other }\end{array}$ & 180 & $\$ 49.79$ & $\$ 103,563$ & $\begin{array}{l}\text { Solar Project } \\
\text { Developer/Sales } \\
\text { Representative } \\
\text { (Wholesale) }\end{array}$ & $\$ 34.30$ & $\$ 71,340$ & $-31 \%$ \\
\hline $\mathrm{N}$ & Chief Executives & 50 & $\$ 88.82$ & $\$ 184,746$ & $\begin{array}{l}\text { Solar Project } \\
\text { Developer/Sales } \\
\text { Representative } \\
\text { (Wholesale) }\end{array}$ & $\$ 34.30$ & $\$ 71,340$ & $-61 \%$ \\
\hline $\mathrm{N}$ & $\begin{array}{l}\text { General and } \\
\text { Operations } \\
\text { Managers }\end{array}$ & 1,090 & $\$ 52.97$ & $\$ 110,178$ & $\begin{array}{l}\text { Solar Project } \\
\text { Developer/Sales } \\
\text { Representative } \\
\text { (Wholesale) }\end{array}$ & $\$ 34.30$ & $\$ 71,340$ & $-35 \%$ \\
\hline $\mathrm{N}$ & $\begin{array}{l}\text { Purchasing } \\
\text { Agents, Except } \\
\text { Wholesale, } \\
\text { Retail, and Farm } \\
\text { Products }\end{array}$ & 210 & $\$ 28.15$ & $\$ 58,552$ & $\begin{array}{l}\text { Solar Marketing } \\
\text { Specialist }\end{array}$ & $\$ 24.98$ & $\$ 51,960$ & $-11 \%$ \\
\hline $\mathrm{N}$ & $\begin{array}{l}\text { Compliance } \\
\text { Officers }\end{array}$ & 110 & $\$ 29.73$ & $\$ 61,838$ & $\begin{array}{l}\text { Code Official with } \\
\text { Solar Expertise }\end{array}$ & $\$ 26.11$ & $\$ 54,320$ & $-12 \%$ \\
\hline $\mathrm{N}$ & $\begin{array}{l}\text { Human } \\
\text { Resources } \\
\text { Specialists }\end{array}$ & 140 & $\$ 30.63$ & $\$ 63,710$ & $\begin{array}{l}\text { Code Official with } \\
\text { Solar Expertise }\end{array}$ & $\$ 26.11$ & $\$ 54,320$ & $-15 \%$ \\
\hline $\mathrm{N}$ & $\begin{array}{l}\text { Training and } \\
\text { Development } \\
\text { Specialists }\end{array}$ & 70 & $\$ 36.46$ & $\$ 75,837$ & $\begin{array}{l}\text { Solar Project } \\
\text { Developer/Sales } \\
\text { Representative } \\
\text { (Wholesale) }\end{array}$ & $\$ 34.30$ & $\$ 71,340$ & $-6 \%$ \\
\hline $\mathrm{N}$ & $\begin{array}{l}\text { Business } \\
\text { Operations }\end{array}$ & 40 & $\$ 38.42$ & $\$ 79,914$ & $\begin{array}{l}\text { Solar Utility } \\
\text { Procurement } \\
\text { Specialist }\end{array}$ & $\$ 38.94$ & $\$ 81,000$ & $1 \%$ \\
\hline
\end{tabular}


Preprint to be published: Edward P. Louie and Joshua M. Pearce. Retraining Investment for U.S. Transition from Coal to Solar Photovoltaic Employment. Energy Economics. (2016). doi:10.1016/j.eneco.2016.05.016

\begin{tabular}{|c|c|c|c|c|c|c|c|c|}
\hline & $\begin{array}{l}\text { Specialists, All } \\
\text { Other }\end{array}$ & & & & & & & \\
\hline $\mathrm{N}$ & $\begin{array}{l}\text { Accountants and } \\
\text { Auditors }\end{array}$ & 240 & $\$ 31.81$ & $\$ 66,165$ & $\begin{array}{l}\text { Solar Project } \\
\text { Developer/Sales } \\
\text { Representative } \\
\text { (Wholesale) }\end{array}$ & $\$ 34.30$ & $\$ 71,340$ & $8 \%$ \\
\hline $\mathrm{N}$ & $\begin{array}{l}\text { Network and } \\
\text { Computer } \\
\text { Systems } \\
\text { Administrators }\end{array}$ & 40 & $\$ 34.58$ & $\$ 71,926$ & $\begin{array}{l}\text { Power Systems } \\
\text { Engineer }\end{array}$ & $\$ 41.05$ & $\$ 85,370$ & $19 \%$ \\
\hline $\mathrm{N}$ & Surveyors & 320 & $\$ 25.39$ & $\$ 52,811$ & $\begin{array}{l}\text { Utility } \\
\text { Interconnection } \\
\text { Engineer }\end{array}$ & $\$ 35.95$ & $\$ 75,065$ & $42 \%$ \\
\hline $\mathrm{N}$ & Civil Engineers & 40 & $\$ 35.50$ & $\$ 73,840$ & $\begin{array}{l}\text { Environmental } \\
\text { Engineer }\end{array}$ & $\$ 37.04$ & $\$ 77,040$ & $4 \%$ \\
\hline $\mathrm{N}$ & $\begin{array}{l}\text { Environmental } \\
\text { Engineers } \\
\end{array}$ & 110 & $\$ 39.27$ & $\$ 81,682$ & $\begin{array}{l}\text { Environmental } \\
\text { Engineer }\end{array}$ & $\$ 37.04$ & $\$ 77,040$ & $-6 \%$ \\
\hline $\mathrm{N}$ & $\begin{array}{l}\text { Health and } \\
\text { Safety } \\
\text { Engineers, } \\
\text { Except Mining } \\
\text { Safety Engineers } \\
\text { and Inspectors }\end{array}$ & 30 & $\$ 39.92$ & $\$ 83,034$ & $\begin{array}{l}\text { Solar Energy } \\
\text { Systems Designer }\end{array}$ & $\$ 43.06$ & $\$ 89,560$ & $8 \%$ \\
\hline $\mathrm{N}$ & $\begin{array}{l}\text { Industrial } \\
\text { Engineers }\end{array}$ & 60 & $\$ 48.82$ & $\$ 101,546$ & Industrial Engineer & $\$ 36.11$ & $\$ 75,110$ & $-26 \%$ \\
\hline $\mathrm{N}$ & $\begin{array}{l}\text { Mechanical } \\
\text { Engineers }\end{array}$ & 40 & $\$ 39.36$ & $\$ 81,869$ & $\begin{array}{l}\text { Mechanical } \\
\text { Engineer }\end{array}$ & $\$ 37.94$ & $\$ 78,910$ & $-4 \%$ \\
\hline $\mathrm{N}$ & $\begin{array}{l}\text { Environmental } \\
\text { Engineering } \\
\text { Technicians }\end{array}$ & 130 & $\$ 24.75$ & $\$ 51,480$ & $\begin{array}{l}\text { Engineering } \\
\text { Technician }\end{array}$ & $\$ 22.48$ & $\$ 46,760$ & $-9 \%$ \\
\hline $\mathrm{N}$ & $\begin{array}{l}\text { Engineering } \\
\text { Technicians, } \\
\text { Except Drafters, } \\
\text { All Other }\end{array}$ & 30 & $\$ 29.19$ & $\$ 60,715$ & $\begin{array}{l}\text { Residential PV } \\
\text { System Designer }\end{array}$ & $\$ 26.36$ & $\$ 54,820$ & $-10 \%$ \\
\hline $\mathrm{N}$ & $\begin{array}{l}\text { Surveying and } \\
\text { Mapping } \\
\text { Technicians }\end{array}$ & 30 & $\$ 17.49$ & $\$ 36,379$ & $\begin{array}{l}\text { Engineering } \\
\text { Technician }\end{array}$ & $\$ 22.48$ & $\$ 46,760$ & $29 \%$ \\
\hline $\mathrm{N}$ & $\begin{array}{l}\text { Geological and } \\
\text { Petroleum } \\
\text { Technicians } \\
\end{array}$ & 120 & $\$ 21.76$ & $\$ 45,261$ & $\begin{array}{l}\text { Engineering } \\
\text { Technician }\end{array}$ & $\$ 22.48$ & $\$ 46,760$ & $3 \%$ \\
\hline $\mathrm{N}$ & Radio Operators & 30 & $\$ 16.59$ & $\$ 34,507$ & $\begin{array}{l}\text { Solar PV Installer } \\
\text { (residential/small } \\
\text { commercial) }\end{array}$ & $\$ 16.34$ & $\$ 33,980$ & $-2 \%$ \\
\hline $\mathrm{N}$ & $\begin{array}{l}\text { Occupational } \\
\text { Health and } \\
\text { Safety } \\
\text { Specialists }\end{array}$ & 260 & $\$ 36.70$ & $\$ 76,336$ & $\begin{array}{l}\text { Environmental } \\
\text { Engineer }\end{array}$ & $\$ 37.04$ & $\$ 77,040$ & $1 \%$ \\
\hline $\mathrm{N}$ & $\begin{array}{l}\text { Occupational } \\
\text { Health and } \\
\text { Safety } \\
\text { Technicians }\end{array}$ & 180 & $\$ 29.00$ & $\$ 60,320$ & $\begin{array}{l}\text { Environmental } \\
\text { Engineer }\end{array}$ & $\$ 37.04$ & $\$ 77,040$ & $28 \%$ \\
\hline $\mathrm{N}$ & Security Guards & 230 & $\$ 12.37$ & $\$ 25,730$ & $\begin{array}{l}\text { Mechanical } \\
\text { Assembler }\end{array}$ & $\$ 13.77$ & $\$ 28,640$ & $11 \%$ \\
\hline
\end{tabular}




\begin{tabular}{|c|c|c|c|c|c|c|c|c|}
\hline $\mathrm{N}$ & $\begin{array}{l}\text { Janitors and } \\
\text { Cleaners, Except } \\
\text { Maids and } \\
\text { Housekeeping } \\
\text { Cleaners }\end{array}$ & 150 & $\$ 12.90$ & $\$ 26,832$ & $\begin{array}{l}\text { Mechanical } \\
\text { Assembler }\end{array}$ & $\$ 13.77$ & $\$ 28,640$ & $7 \%$ \\
\hline $\mathrm{N}$ & $\begin{array}{l}\text { Sales } \\
\text { Representatives, } \\
\text { Services, All } \\
\text { Other } \\
\end{array}$ & 40 & $\$ 33.53$ & $\$ 69,742$ & $\begin{array}{l}\text { Solar Project } \\
\text { Developer/Sales } \\
\text { Representative } \\
\text { (Wholesale) }\end{array}$ & $\$ 34.30$ & $\$ 71,340$ & $2 \%$ \\
\hline $\mathrm{N}$ & $\begin{array}{l}\text { First-Line } \\
\text { Supervisors of } \\
\text { Office and } \\
\text { Administrative } \\
\text { Support Workers }\end{array}$ & 90 & $\$ 27.43$ & $\$ 57,054$ & $\begin{array}{l}\text { Quality Assurance } \\
\text { Specialist }\end{array}$ & $\$ 27.89$ & $\$ 58,020$ & $2 \%$ \\
\hline $\mathrm{N}$ & $\begin{array}{l}\text { Bookkeeping, } \\
\text { Accounting, and } \\
\text { Auditing Clerks }\end{array}$ & 340 & $\$ 18.73$ & $\$ 38,958$ & $\begin{array}{l}\text { Solar Sales } \\
\text { Representative } \\
\text { (Retail) }\end{array}$ & $\$ 23.76$ & $\$ 49,410$ & $27 \%$ \\
\hline $\mathrm{N}$ & $\begin{array}{l}\text { Payroll and } \\
\text { Timekeeping } \\
\text { Clerks }\end{array}$ & 100 & $\$ 17.73$ & $\$ 36,878$ & $\begin{array}{l}\text { Solar Sales } \\
\text { Representative } \\
\text { (Retail) }\end{array}$ & $\$ 23.76$ & $\$ 49,410$ & $34 \%$ \\
\hline $\mathrm{N}$ & $\begin{array}{l}\text { Human } \\
\text { Resources } \\
\text { Assistants, } \\
\text { Except Payroll } \\
\text { and Timekeeping }\end{array}$ & 50 & $\$ 17.91$ & $\$ 37,253$ & $\begin{array}{l}\text { Solar Sales } \\
\text { Representative } \\
\text { (Retail) }\end{array}$ & $\$ 23.76$ & $\$ 49,410$ & $33 \%$ \\
\hline $\mathrm{N}$ & $\begin{array}{l}\text { Receptionists } \\
\text { and Information } \\
\text { Clerks }\end{array}$ & 70 & $\$ 11.24$ & $\$ 23,379$ & $\begin{array}{l}\text { Solar Installation } \\
\text { Helper }\end{array}$ & $\$ 12.86$ & $\$ 26,760$ & $14 \%$ \\
\hline $\mathrm{N}$ & $\begin{array}{l}\text { Dispatchers, } \\
\text { Except Police, } \\
\text { Fire, and } \\
\text { Ambulance }\end{array}$ & 210 & $\$ 21.21$ & $\$ 44,117$ & $\begin{array}{l}\text { Solar Sales } \\
\text { Representative } \\
\text { (Retail) }\end{array}$ & $\$ 23.76$ & $\$ 49,410$ & $12 \%$ \\
\hline $\mathrm{N}$ & $\begin{array}{l}\text { Production, } \\
\text { Planning, and } \\
\text { Expediting } \\
\text { Clerks }\end{array}$ & 120 & $\$ 26.19$ & $\$ 54,475$ & $\begin{array}{l}\text { Solar Marketing } \\
\text { Specialist }\end{array}$ & $\$ 24.98$ & $\$ 51,960$ & $-5 \%$ \\
\hline $\mathrm{N}$ & $\begin{array}{l}\text { Shipping, } \\
\text { Receiving, and } \\
\text { Traffic Clerks }\end{array}$ & 150 & $\$ 19.58$ & $\$ 40,726$ & $\begin{array}{l}\text { Solar PV Installer } \\
\text { (residential/small } \\
\text { commercial) }\end{array}$ & $\$ 16.34$ & $\$ 33,980$ & $-17 \%$ \\
\hline $\mathrm{N}$ & $\begin{array}{l}\text { Stock Clerks and } \\
\text { Order Fillers }\end{array}$ & 440 & $\$ 18.55$ & $\$ 38,584$ & $\begin{array}{l}\text { Computer } \\
\text { Numerical Control } \\
\text { (CNC) Operator }\end{array}$ & $\$ 17.26$ & $\$ 35,890$ & $-7 \%$ \\
\hline $\mathrm{N}$ & $\begin{array}{l}\text { Weighers, } \\
\text { Measurers, } \\
\text { Checkers, and } \\
\text { Samplers, } \\
\text { Recordkeeping }\end{array}$ & 60 & $\$ 17.37$ & $\$ 36,130$ & $\begin{array}{l}\text { Computer } \\
\text { Numerical Control } \\
\text { (CNC) Operator }\end{array}$ & $\$ 17.26$ & $\$ 35,890$ & $-1 \%$ \\
\hline $\mathrm{N}$ & $\begin{array}{l}\text { Executive } \\
\text { Secretaries and } \\
\text { Executive } \\
\text { Administrative } \\
\text { Assistants } \\
\end{array}$ & 80 & $\$ 23.75$ & $\$ 49,400$ & $\begin{array}{l}\text { Code Official with } \\
\text { Solar Expertise }\end{array}$ & $\$ 26.11$ & $\$ 54,320$ & $10 \%$ \\
\hline $\mathrm{N}$ & $\begin{array}{l}\text { Secretaries and } \\
\text { Administrative }\end{array}$ & 170 & $\$ 14.59$ & $\$ 30,347$ & Solar Site Assessor & 16 & 33280 & $10 \%$ \\
\hline
\end{tabular}




\begin{tabular}{|c|c|c|c|c|c|c|c|c|}
\hline & $\begin{array}{l}\text { Assistants, } \\
\text { Except Legal, } \\
\text { Medical, and } \\
\text { Executive }\end{array}$ & & & & & & & \\
\hline $\mathrm{N}$ & $\begin{array}{l}\text { Office Clerks, } \\
\text { General }\end{array}$ & 750 & $\$ 15.69$ & $\$ 32,635$ & Solar Site Assessor & 16 & 33280 & $2 \%$ \\
\hline $\mathrm{N}$ & $\begin{array}{l}\text { First-Line } \\
\text { Supervisors of } \\
\text { Construction } \\
\text { Trades and } \\
\text { Extraction } \\
\text { Workers }\end{array}$ & 4,330 & $\$ 37.92$ & $\$ 78,874$ & $\begin{array}{l}\text { Solar Installation } \\
\text { Contractor }\end{array}$ & $\$ 39.58$ & $\$ 82,330$ & $4 \%$ \\
\hline $\mathrm{N}$ & Carpenters & 50 & $\$ 24.34$ & $\$ 50,627$ & $\begin{array}{l}\text { Solar PV Technician } \\
\text { (commercial/utility) }\end{array}$ & $\$ 29.94$ & $\$ 62,270$ & $23 \%$ \\
\hline $\mathrm{N}$ & $\begin{array}{l}\text { Construction } \\
\text { Laborers }\end{array}$ & 1,510 & $\$ 20.54$ & $\$ 42,723$ & $\begin{array}{l}\text { Solar PV Installer } \\
\text { (residential/small } \\
\text { commercial) }\end{array}$ & $\$ 16.34$ & $\$ 33,980$ & $-20 \%$ \\
\hline $\mathrm{N}$ & $\begin{array}{l}\text { Operating } \\
\text { Engineers and } \\
\text { Other } \\
\text { Construction } \\
\text { Equipment } \\
\text { Operators } \\
\end{array}$ & 9,950 & $\$ 21.62$ & $\$ 44,970$ & $\begin{array}{l}\text { Advanced } \\
\text { Manufacturing } \\
\text { Technician }\end{array}$ & $\$ 23.82$ & $\$ 49,550$ & $10 \%$ \\
\hline $\mathrm{N}$ & Electricians & 3,820 & $\$ 28.05$ & $\$ 58,344$ & $\begin{array}{l}\text { Electrician with } \\
\text { Solar Expertise }\end{array}$ & $\$ 21.98$ & $\$ 47,180$ & $-22 \%$ \\
\hline $\mathrm{N}$ & $\begin{array}{l}\text { Plumbers, } \\
\text { Pipefitters, and } \\
\text { Steamfitters }\end{array}$ & 60 & $\$ 25.30$ & $\$ 52,624$ & $\begin{array}{l}\text { Plumber with Solar } \\
\text { Expertise }\end{array}$ & $\$ 22.27$ & $\$ 46,320$ & $-12 \%$ \\
\hline $\mathrm{N}$ & $\begin{array}{l}\text { Rail-Track } \\
\text { Laying and } \\
\text { Maintenance } \\
\text { Equipment } \\
\text { Operators }\end{array}$ & 90 & $\$ 25.50$ & $\$ 53,040$ & $\begin{array}{l}\text { Advanced } \\
\text { Manufacturing } \\
\text { Technician }\end{array}$ & $\$ 23.82$ & $\$ 49,550$ & $-7 \%$ \\
\hline $\mathrm{N}$ & $\begin{array}{l}\text { Earth Drillers, } \\
\text { Except Oil and } \\
\text { Gas }\end{array}$ & 560 & $\$ 23.65$ & $\$ 49,192$ & $\begin{array}{l}\text { Advanced } \\
\text { Manufacturing } \\
\text { Technician }\end{array}$ & $\$ 23.82$ & $\$ 49,550$ & $1 \%$ \\
\hline $\mathrm{N}$ & $\begin{array}{l}\text { Helpers-- } \\
\text { Extraction } \\
\text { Workers }\end{array}$ & 2,620 & $\$ 21.47$ & $\$ 44,658$ & $\begin{array}{l}\text { Solar Installation } \\
\text { Helper }\end{array}$ & $\$ 12.86$ & $\$ 26,760$ & $-40 \%$ \\
\hline $\mathrm{N}$ & $\begin{array}{l}\text { First-Line } \\
\text { Supervisors of } \\
\text { Mechanics, } \\
\text { Installers, and } \\
\text { Repairers }\end{array}$ & 1,300 & $\$ 39.55$ & $\$ 82,264$ & $\begin{array}{l}\text { Solar Installation } \\
\text { Contractor }\end{array}$ & $\$ 39.58$ & $\$ 82,330$ & $0 \%$ \\
\hline $\mathrm{N}$ & $\begin{array}{l}\text { Electric Motor, } \\
\text { Power Tool, and } \\
\text { Related } \\
\text { Repairers }\end{array}$ & 40 & $\$ 25.42$ & $\$ 52,874$ & $\begin{array}{l}\text { Process Control } \\
\text { Technician }\end{array}$ & $\$ 27.89$ & $\$ 58,020$ & $10 \%$ \\
\hline $\mathrm{N}$ & $\begin{array}{l}\text { Bus and Truck } \\
\text { Mechanics and } \\
\text { Diesel Engine } \\
\text { Specialists }\end{array}$ & 910 & $\$ 29.77$ & $\$ 61,922$ & $\begin{array}{l}\text { Process Control } \\
\text { Technician }\end{array}$ & $\$ 27.89$ & $\$ 58,020$ & $-6 \%$ \\
\hline $\mathrm{N}$ & $\begin{array}{l}\text { Mobile Heavy } \\
\text { Equipment }\end{array}$ & 3,380 & $\$ 25.02$ & $\$ 52,042$ & $\begin{array}{l}\text { Process Control } \\
\text { Technician }\end{array}$ & $\$ 27.89$ & $\$ 58,020$ & $11 \%$ \\
\hline
\end{tabular}




\begin{tabular}{|c|c|c|c|c|c|c|c|c|}
\hline & $\begin{array}{l}\text { Mechanics, } \\
\text { Except Engines }\end{array}$ & & & & & & & \\
\hline $\mathrm{N}$ & $\begin{array}{l}\text { Tire Repairers } \\
\text { and Changers }\end{array}$ & 70 & $\$ 13.85$ & $\$ 28,808$ & $\begin{array}{l}\text { Mechanical } \\
\text { Assembler }\end{array}$ & $\$ 13.77$ & $\$ 28,640$ & $-1 \%$ \\
\hline $\mathrm{N}$ & $\begin{array}{l}\text { Industrial } \\
\text { Machinery } \\
\text { Mechanics }\end{array}$ & 1,580 & $\$ 25.32$ & $\$ 52,666$ & $\begin{array}{l}\text { Process Control } \\
\text { Technician }\end{array}$ & $\$ 27.89$ & $\$ 58,020$ & $10 \%$ \\
\hline $\mathrm{N}$ & $\begin{array}{l}\text { Maintenance } \\
\text { Workers, } \\
\text { Machinery } \\
\end{array}$ & 1,180 & $\$ 23.20$ & $\$ 48,256$ & $\begin{array}{l}\text { Advanced } \\
\text { Manufacturing } \\
\text { Technician } \\
\end{array}$ & $\$ 23.82$ & $\$ 49,550$ & $3 \%$ \\
\hline $\mathrm{N}$ & Millwrights & 140 & $\$ 31.70$ & $\$ 65,936$ & $\begin{array}{l}\text { Solar PV Technician } \\
\text { (commercial/utility) }\end{array}$ & $\$ 29.94$ & $\$ 62,270$ & $-6 \%$ \\
\hline $\mathrm{N}$ & $\begin{array}{l}\text { Maintenance and } \\
\text { Repair Workers, } \\
\text { General }\end{array}$ & 2,110 & $\$ 20.28$ & $\$ 42,182$ & $\begin{array}{l}\text { Solar PV Installer } \\
\text { (residential/small } \\
\text { commercial) }\end{array}$ & $\$ 16.34$ & $\$ 33,980$ & $-19 \%$ \\
\hline $\mathrm{N}$ & $\begin{array}{l}\text { Helpers-- } \\
\text { Installation, } \\
\text { Maintenance, } \\
\text { and Repair } \\
\text { Workers } \\
\end{array}$ & 230 & $\$ 18.52$ & $\$ 38,522$ & $\begin{array}{l}\text { Computer } \\
\text { Numerical Control } \\
\text { (CNC) Operator }\end{array}$ & $\$ 17.26$ & $\$ 35,890$ & $-7 \%$ \\
\hline $\mathrm{N}$ & $\begin{array}{l}\text { First-Line } \\
\text { Supervisors of } \\
\text { Production and } \\
\text { Operating } \\
\text { Workers }\end{array}$ & 770 & $\$ 36.27$ & $\$ 75,442$ & $\begin{array}{l}\text { Solar Installation } \\
\text { Contractor }\end{array}$ & $\$ 39.58$ & $\$ 82,330$ & $9 \%$ \\
\hline $\mathrm{N}$ & Machinists & 40 & $\$ 26.79$ & $\$ 55,723$ & $\begin{array}{l}\text { Process Control } \\
\text { Technician }\end{array}$ & $\$ 27.89$ & $\$ 58,020$ & $4 \%$ \\
\hline $\mathrm{N}$ & $\begin{array}{l}\text { Welders, Cutters, } \\
\text { Solderers, and } \\
\text { Brazers }\end{array}$ & 970 & $\$ 25.29$ & $\$ 52,603$ & $\begin{array}{l}\text { Instrumentation and } \\
\text { Electronics } \\
\text { Technician }\end{array}$ & $\$ 26.36$ & $\$ 54,820$ & $4 \%$ \\
\hline $\mathrm{N}$ & $\begin{array}{l}\text { Plant and System } \\
\text { Operators, All } \\
\text { Other }\end{array}$ & 150 & $\$ 21.46$ & $\$ 44,637$ & $\begin{array}{l}\text { Solar PV Technician } \\
\text { (commercial/utility) }\end{array}$ & $\$ 29.94$ & $\$ 62,270$ & $40 \%$ \\
\hline $\mathrm{N}$ & $\begin{array}{l}\text { Separating, } \\
\text { Filtering, } \\
\text { Clarifying, } \\
\text { Precipitating, } \\
\text { and Still } \\
\text { Machine Setters, } \\
\text { Operators, and } \\
\text { Tenders } \\
\end{array}$ & 190 & $\$ 22.48$ & $\$ 46,758$ & $\begin{array}{l}\text { Solar PV Installer } \\
\text { (residential/small } \\
\text { commercial) }\end{array}$ & $\$ 16.34$ & $\$ 33,980$ & $-27 \%$ \\
\hline $\mathrm{N}$ & $\begin{array}{l}\text { Crushing, } \\
\text { Grinding, and } \\
\text { Polishing } \\
\text { Machine Setters, } \\
\text { Operators, and } \\
\text { Tenders } \\
\end{array}$ & 380 & $\$ 21.48$ & $\$ 44,678$ & $\begin{array}{l}\text { Solar PV Installer } \\
\text { (residential/small } \\
\text { commercial) }\end{array}$ & $\$ 16.34$ & $\$ 33,980$ & $-24 \%$ \\
\hline $\mathrm{N}$ & $\begin{array}{l}\text { Inspectors, } \\
\text { Testers, Sorters, } \\
\text { Samplers, and } \\
\text { Weighers } \\
\end{array}$ & 280 & $\$ 21.89$ & $\$ 45,531$ & $\begin{array}{l}\text { Quality Assurance } \\
\text { Specialist }\end{array}$ & $\$ 27.89$ & $\$ 58,020$ & $27 \%$ \\
\hline $\mathrm{N}$ & $\begin{array}{l}\text { Cleaning, } \\
\text { Washing, and } \\
\text { Metal Pickling }\end{array}$ & 40 & $\$ 19.78$ & $\$ 41,142$ & $\begin{array}{l}\text { Solar PV Installer } \\
\text { (residential/small } \\
\text { commercial) }\end{array}$ & $\$ 16.34$ & $\$ 33,980$ & $-17 \%$ \\
\hline
\end{tabular}




\begin{tabular}{|c|c|c|c|c|c|c|c|c|}
\hline & $\begin{array}{l}\text { Equipment } \\
\text { Operators and } \\
\text { Tenders }\end{array}$ & & & & & & & \\
\hline $\mathrm{N}$ & $\begin{array}{l}\text { Helpers-- } \\
\text { Production } \\
\text { Workers } \\
\end{array}$ & 730 & $\$ 24.74$ & $\$ 51,459$ & $\begin{array}{l}\text { Solar PV Installer } \\
\text { (residential/small } \\
\text { commercial) }\end{array}$ & $\$ 16.34$ & $\$ 33,980$ & $-34 \%$ \\
\hline $\mathrm{N}$ & $\begin{array}{l}\text { Production } \\
\text { Workers, All } \\
\text { Other }\end{array}$ & 70 & $\$ 25.32$ & $\$ 52,666$ & $\begin{array}{l}\text { Solar PV Installer } \\
\text { (residential/small } \\
\text { commercial) }\end{array}$ & $\$ 16.34$ & $\$ 33,980$ & $-35 \%$ \\
\hline $\mathrm{N}$ & $\begin{array}{l}\text { First-Line } \\
\text { Supervisors of } \\
\text { Helpers, } \\
\text { Laborers, and } \\
\text { Material Movers, } \\
\text { Hand }\end{array}$ & 350 & $\$ 27.02$ & $\$ 56,202$ & $\begin{array}{l}\text { Solar PV Technician } \\
\text { (commercial/utility) }\end{array}$ & $\$ 29.94$ & $\$ 62,270$ & $11 \%$ \\
\hline $\mathrm{N}$ & $\begin{array}{l}\text { First-Line } \\
\text { Supervisors of } \\
\text { Transportation } \\
\text { and Material- } \\
\text { Moving Machine } \\
\text { and Vehicle } \\
\text { Operators } \\
\end{array}$ & 560 & $\$ 34.57$ & $\$ 71,906$ & $\begin{array}{l}\text { Solar PV Technician } \\
\text { (commercial/utility) }\end{array}$ & $\$ 29.94$ & $\$ 62,270$ & $-13 \%$ \\
\hline $\mathrm{N}$ & $\begin{array}{l}\text { Bus Drivers, } \\
\text { Transit and } \\
\text { Intercity }\end{array}$ & 100 & $\$ 16.92$ & $\$ 35,194$ & $\begin{array}{l}\text { Computer } \\
\text { Numerical Control } \\
\text { (CNC) Operator }\end{array}$ & $\$ 17.26$ & $\$ 35,890$ & $2 \%$ \\
\hline $\mathrm{N}$ & $\begin{array}{l}\text { Heavy and } \\
\text { Tractor-Trailer } \\
\text { Truck Drivers } \\
\end{array}$ & 3,180 & $\$ 20.73$ & $\$ 43,118$ & $\begin{array}{l}\text { Solar PV Installer } \\
\text { (residential/small } \\
\text { commercial) }\end{array}$ & $\$ 16.34$ & $\$ 33,980$ & $-21 \%$ \\
\hline $\mathrm{N}$ & $\begin{array}{l}\text { Light Truck or } \\
\text { Delivery } \\
\text { Services Drivers }\end{array}$ & 90 & $\$ 9.24$ & $\$ 19,219$ & $\begin{array}{l}\text { Mechanical } \\
\text { Assembler }\end{array}$ & $\$ 13.77$ & $\$ 28,640$ & $49 \%$ \\
\hline $\mathrm{N}$ & $\begin{array}{l}\text { Rail Yard } \\
\text { Engineers, } \\
\text { Dinkey } \\
\text { Operators, and } \\
\text { Hostlers } \\
\end{array}$ & 150 & $\$ 24.97$ & $\$ 51,938$ & $\begin{array}{l}\text { Solar PV Installer } \\
\text { (residential/small } \\
\text { commercial) }\end{array}$ & $\$ 16.34$ & $\$ 33,980$ & $-35 \%$ \\
\hline $\mathrm{N}$ & $\begin{array}{l}\text { Industrial Truck } \\
\text { and Tractor } \\
\text { Operators }\end{array}$ & 800 & $\$ 19.75$ & $\$ 41,080$ & $\begin{array}{l}\text { Computer } \\
\text { Numerical Control } \\
\text { (CNC) Operator }\end{array}$ & $\$ 17.26$ & $\$ 35,890$ & $-13 \%$ \\
\hline $\mathrm{N}$ & $\begin{array}{l}\text { Cleaners of } \\
\text { Vehicles and } \\
\text { Equipment } \\
\end{array}$ & 90 & $\$ 14.52$ & $\$ 30,202$ & $\begin{array}{l}\text { Computer } \\
\text { Numerical Control } \\
\text { (CNC) Operator }\end{array}$ & $\$ 17.26$ & $\$ 35,890$ & $19 \%$ \\
\hline $\mathrm{N}$ & $\begin{array}{l}\text { Laborers and } \\
\text { Freight, Stock, } \\
\text { and Material } \\
\text { Movers, Hand }\end{array}$ & 1,130 & $\$ 18.70$ & $\$ 38,896$ & $\begin{array}{l}\text { Solar PV Installer } \\
\text { (residential/small } \\
\text { commercial) }\end{array}$ & $\$ 16.34$ & $\$ 33,980$ & $-13 \%$ \\
\hline $\mathrm{N}$ & $\begin{array}{l}\text { Pump Operators, } \\
\text { Except Wellhead } \\
\text { Pumpers }\end{array}$ & 120 & $\$ 22.59$ & $\$ 46,987$ & $\begin{array}{l}\text { Solar PV Installer } \\
\text { (residential/small } \\
\text { commercial) }\end{array}$ & $\$ 16.34$ & $\$ 33,980$ & $-28 \%$ \\
\hline $\mathrm{N}$ & $\begin{array}{l}\text { Tank Car, Truck, } \\
\text { and Ship Loaders }\end{array}$ & 100 & $\$ 22.60$ & $\$ 47,008$ & $\begin{array}{l}\text { Solar PV Installer } \\
\text { (residential/small } \\
\text { commercial) }\end{array}$ & $\$ 16.34$ & $\$ 33,980$ & $-28 \%$ \\
\hline
\end{tabular}




\section{Appendix 4. Employment Transitions Between Coal-Fired Power Plant and Solar Photovoltaic Industries}

\begin{tabular}{|c|c|c|c|c|c|c|c|c|}
\hline $\begin{array}{c}\text { Train } \\
\text { ing }\end{array}$ & Occupation Title & $\begin{array}{l}\text { Empl } \\
\text { oyees }\end{array}$ & $\begin{array}{c}\text { Median } \\
\text { hourly } \\
\text { wage }\end{array}$ & $\begin{array}{c}\text { Annual } \\
\text { median } \\
\text { wage }\end{array}$ & Closest PV Job & $\begin{array}{c}\text { Median } \\
\text { hourly } \\
\text { wage }\end{array}$ & $\begin{array}{l}\text { Annual } \\
\text { median } \\
\text { wage }\end{array}$ & $\begin{array}{c}\Delta \\
\text { Wage } \\
\%\end{array}$ \\
\hline $\mathrm{N}$ & $\begin{array}{l}\text { Power } \\
\text { Distributors, } \\
\text { Dispatchers, } \\
\text { Systems/Network } \\
\text { Operators }\end{array}$ & 2410 & $\$ 37.01$ & $\$ 76,981$ & $\begin{array}{l}\text { Utility } \\
\text { Interconnection } \\
\text { Engineer }\end{array}$ & $\$ 35.95$ & $\$ 75,065$ & $-3 \%$ \\
\hline $\mathrm{N}$ & $\begin{array}{l}\text { Power Plant } \\
\text { Operator }\end{array}$ & 11181 & $\$ 32.74$ & $\$ 68,099$ & $\begin{array}{l}\text { Power Systems } \\
\text { Engineer }\end{array}$ & $\$ 41.05$ & $\$ 85,370$ & $25 \%$ \\
\hline $\mathrm{N}$ & $\begin{array}{l}\text { Electrical and } \\
\text { Electronics } \\
\text { Repairers, } \\
\text { Powerhouse, } \\
\text { Substation, and } \\
\text { Relay }\end{array}$ & 5936 & $\$ 33.33$ & $\$ 69,326$ & $\begin{array}{l}\text { Power Systems } \\
\text { Engineer }\end{array}$ & $\$ 41.05$ & $\$ 85,370$ & $23 \%$ \\
\hline $\mathrm{N}$ & $\begin{array}{l}\text { Electrical } \\
\text { Engineers }\end{array}$ & 6533 & $\$ 42.26$ & $\$ 87,901$ & Electrical Engineer & $\$ 32.58$ & $\$ 83,110$ & $-23 \%$ \\
\hline $\mathrm{Y}$ & $\begin{array}{l}\text { Coal-Fired Power } \\
\text { Plant Others }\end{array}$ & 34481 & $\$ 28.85$ & $\$ 60,000$ & $\begin{array}{l}\text { Solar PV Technician } \\
\text { (commercial/utility) }\end{array}$ & $\$ 29.94$ & $\$ 62,270$ & $4 \%$ \\
\hline
\end{tabular}

